\title{
Application and State of Development for Remote Chemical Sensors in Environmental Monitoring --
A Literature Review
}

\section{Topical Report}

\section{J.F. Schabron \\ N.D. Niss \\ B.K. Hart}

September 1991

\section{DISCLAIMER}

This report was prepared as an account of work sponsored by an agency of the United States Government. Neither the United States Government nor any agency thereof, nor any of their ernployees, makes any warranty, express or implied, or assumes any legal liability or responsibility for the accuracy, completeness, or usefulness of any information, apparatus, product, or process disclosed, or represents that its use would not infringe privately owned rights. Reference herein to any specific commercial product, process, or service by trade name, trademark, manufacturer, or otherwise does not necessarily constitute or imply its endorsement, recommendation, or favoring by the United States Government or any agency thereof. The views and opinions of authors expressed herein do not necessarily state or reflect those of the United States Government or any agency thereof.
\end{abstract}

Work Performed Under Cooperative Agreement No.: DE-FC21-86MC1 1076

For

U.S. Department of Energy

Office of Fossil Energy

Morgantown Energy Technology Center

Morgantown, West Virginia

By

Western Research Institute

Laramie, Wyoming

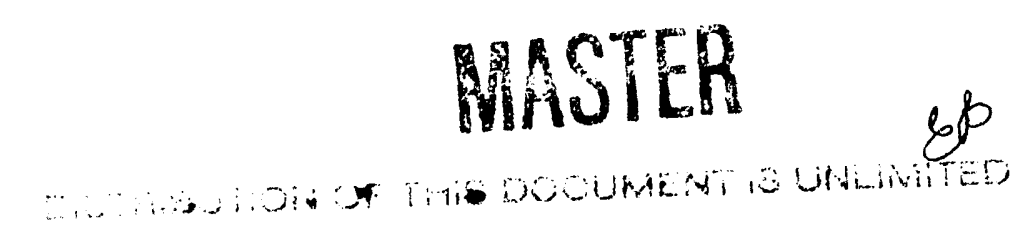




\section{DISCLAIMER}

This report was pre iared as an account of work sponsored by an agency of the United States Government. Neither the United States Government nor any agency thereof, nor any of their employees makes any warranty, express or implied, or assumes any legal liability or responsibility for the accuracy, completeness or usefulness of any information, apparatus, product, or process disclosed, or represents that its use would not infringe privately owned rights. Reference herein to any specific commercial product, process, or service by trade name, trademark, manufacturer, or otherwise, does not necessarily constitute or imply its endorsement, recommendation, or favoring by the United States Government or any agency thereof. The views and opinions of authors expressed herein do not necessarily state or reflect those of the United States Government or any agency thereof.

This report has been reproduced directly from the best available copy.

Available to DOE and DOE contractors from the Office of Scientific and Technical Information, P.O. Box 62, Oak Ridge, TN 37831; prices available from (615)576-8401, FTS 626-8401.

Available to the public from the National Technical Information Service, U.S. Department of Commerce, 5285 Port Royal Rd., Springfield, VA 22161. 


\title{
Application and State of Development for Remote Chemical Sensors in Environmental Monitoring -- \\ A Literature Review
}

\author{
Topical Report
}

\author{
J.F. Schabron \\ N.D. Niss \\ B.K. Hart
}

Work Performed Under Cooperative Agreement No.: DE-FC21-86MC11076

\author{
For \\ U.S. Department of Energy \\ Office of Fossil Energy \\ Morgantown Energy Technology Center \\ P.O. Box 880 \\ Morgantown, West Virginia 26507-0880 \\ By \\ Western Research Institute \\ P.O. Box 3395 \\ University Station \\ Laramie, Wyoming 82071
}

September 1991 


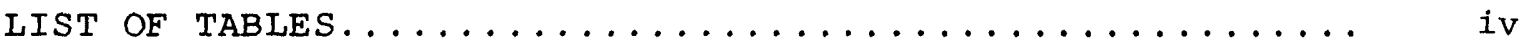

SUMMARY $\ldots \ldots \ldots \ldots \ldots \ldots \ldots \ldots \ldots \ldots \ldots \ldots \ldots \ldots \ldots \ldots \ldots \ldots \ldots$

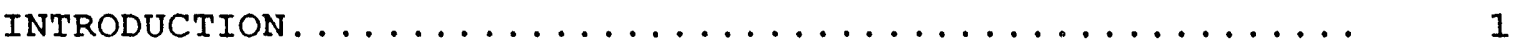

Background........................... 1

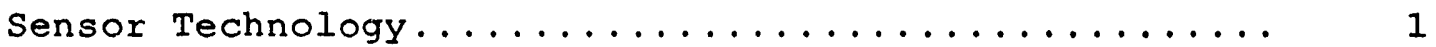

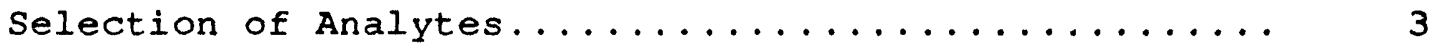

Safe Drinking water Act...................... 4

Resource Conservation and Recovery Act............ 5

Water Quality Act........................ 7

Comprehensive Environmental Response,

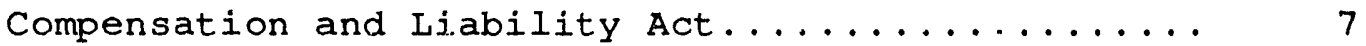

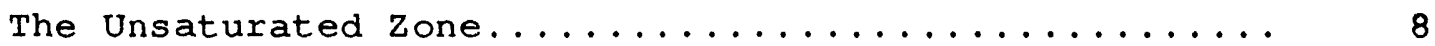

Evaluation of Sensor Characteristics............ 9

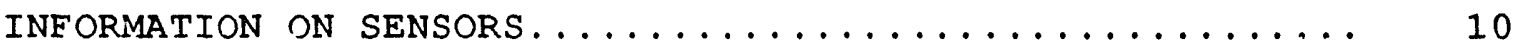

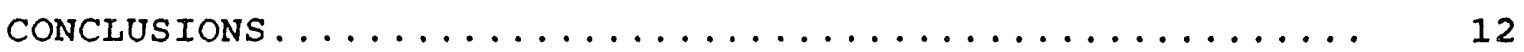

ACKNOWLEDGMENTS ........................ 13

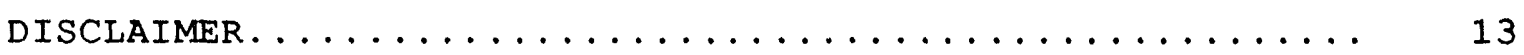

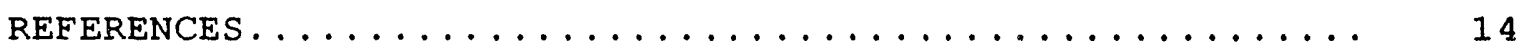

APPENDIX A. Organic Compound Sensors................ 23

APPENDIX B. Metals sensors...................... 71

APPENDIX C. Anion and Cation Sensors.............. 88

APPENDIX D. $\mathrm{pH}$ Sensors........................ 102

APPENDIX E. Miscellaneous Sensors.................. 112 


\section{LIST OF TABLFS}

Table

Page

1. 1991 Drinking Water Priority List...............

2. Inorganic Chemicals Governed Under

the National Primary and Secondary

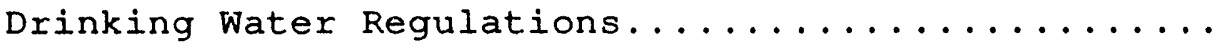

3. Organic Chemicals Governed Under

the National Primary Drinking

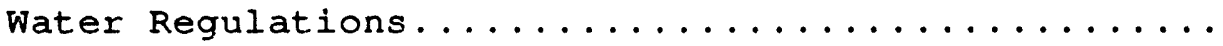

4. TCLP Analytes and Regulatory Limits

in $\mathrm{mg} / \mathrm{L}$ for Extracts....................... 20

5. Priority Pollutant List..................... 21

6. Contract Laboratory Program

Hazardous Substance List Metals............... 
A study was performed on chemical sensor technology currently available and under development. The information was compiled into a format wherein information on the sensors is listed in a comparable manner. An introductory section is provided to illustrate the regulatory environment in which such sensor technology will be used. This information should allow corporations or federal agencies ready access to useful information for the potential licensing of sensor technology for commercial development or specific environmental monitoring operations. Although every attempt was made to identify as many chemical sensors as possible, we recognize that some may be missed inadvertently. The accurcy of the information provided by the various sources regarding the state of development for the various sensors was not verified. Judgements or opinions regarding the actual state of development or utility of these devices are not included in this report. However, we feel that this report accurately reflects the state of the art at the present time. 


\section{INTRODOCTION}

\section{Background}

The capability to detect and monitor groundwater contaminants using real-time in situ measurements promises to be a valuable tool in the environmental industry. The development of chemical sensors to provide in situ information on groundwater parameters will eliminate many problems and significantly lower costs associated with conventional sampling and analysis techniques. Conventional sampling techniques may affect the integrity of the sample in a variety of ways. Changes in the partial pressure of $\mathrm{CO}_{2}$ during sampling may affect the sample $\mathrm{pH}$, and pressure changes may make quantitation of volatile organic compounds difficult. Swedish scientists have found substantial differences between in situ and surface oxidation-reduction potentials (Eh), which may affect the mobility of certain contaminants (Murphy and Hostetler 1989). Other potential problems may result during transport and storage of samples from the field to the laboratory such as oxidation of contaminants due to ultraviolet-light exposure or improper preservation techniques and biological conversion of solutes. A comprehensive treatment of groundwater monitoring issues has been published recently (Nielsen, 1991).

Conventional sampling and analysis techniques may have high costs associated with them. Regulations covering groundwater monitoring for contaminant release and transport are continually being expanded by the U.S. Environmental protection Agency (EPA). Current technology for the analysis of groundwater samples requires a vast array of expensive equipment, highly trained personnel, and sometimes extensive data interpretation. Drinking water regulations also are expanding in the number of chemicals which will have to be determined routinely. As monitoring programs expand and regulations become more stringent, associated sampling and analysis costs will escalate considerably unless new technology is developed in the future to monitor water contamination in real-time. The development of in situ chemical sensor capabilities will help lower analytical costs in the long term, provide valuable information during remediation activities, and help optimize treatment techniques.

\section{Sensox Technology}

A significant amount of development work is taking place in the area of fiber optic based chemical sensors using various 
types of optical spectroscory. These offer advantages over electrochemical-based sensors for groundwater monitoring because they do not experience electrical interference, do not require a reference tectrode, and are considered to maintain more stable calibration (zhujun et al. 1986). Sensors responding to changes in mass, such as quartz crystal microbalance (QCM) and surface acoustic-wave devices (SAW), are also under development. SAW devices are used primarily for monitoring volatile chemicals in air or headspace (Janata 1989); however, they can be covered with hydrophobic semipermeable membranes for detection of volatile species in aqueous solution. Another area of development is sensor arrays (Stetter 1984). Typically applied to airborne or headspace volatiles, the signals from an array of sensors (electrochemical, SAW, etc.) each with a different response to the analytes of interest, is interpreted by various computer algorithms to provide an analysis or an empirical quality control decision concerning the mixture. With appropriate sensor design, this concept can be used for groundwater monitoring.

Seitz (1984, 1988) and Eccles et al. (1987) provided comprehensive descriptions of the various considerations and technologies used for fiber-optic chemical sensors. Briefly, these sensors employ simple or complex optical techniques including absorbance, reflectance, fluorescence, fluorescence quenching, refractive index, or Raman scattering. The excitation source can be a lamp, light emitting diode, or laser. The light interacts directly with the analyte or indirectly with an indicator compound or the product of a chemical reaction involving the analyte.

Typically, the probe radiation and detected radiation are transmitted through the same fiber bundle or through two, bifurcated bundles. Various configurations are used at or near the sensor tip to maximize sensitivity. These include fiber coatings for evanescent wave sensing, chemical exchanges or reactions in reagent reservoirs, indicators coated on surfaces or on polymeric particles or fibers to increase surface area, and reflection from a mirror for direct solution monitoring. Detection is by phototube, photomultiplier, or a solid-state system such as a charged-coupled device (CCD), with wavelength filters, or dispersion devices such as a diffraction grating monochromator. Sensitivity (ppb, ppm) depends on the particular analyte and sensor design. Linear range of signal response for an analyte is important for quantitative measurements, as is the drift of signal response over time and the signal level at 
various temperatures. Another important consideration is reversibility. A reversible sensor can be left in place and will respond to varying concentrations of analyte over time. The useful lifetime of a sensor is an important consideration. An irreversible sensor is used like a dosimeter for a single measurement. Ideally, calibration can be performed in situ using a relative relationship such as the relative reflectance at two wavelengths. In some cases, calibration may be performed by pumping reagent through the sensor cell.

The purpose of this report is to provide information on the regulatory issues related to environmental monitoring, and the in situ sensing capabilities currently available or under development for monitoring chemical contaminants in groundwater and in the unsaturated, or vadose, zone.

\section{selection of Analytes}

In situ sensing involves various physical parameters as well as inorganic and organic analytes. The physical parameters for which sensors are widely available include temperature, conductivity, and pressure. Other common sensors include dissolved oxygen, $\mathrm{pH}$, and $\mathrm{Eh}$. Accurate $\mathrm{pH}$ measurements are critical to compare data on analytes measured in situ and analytes measured in the laboratory. Any changes in pH during sampling or transport may affect the solubility of certain species. The oxidation-reduction potential (Eh) affects the transport of species within an environment. For example, during bioremediation projects accurate $\mathrm{Eh}$ measurements are essential in determining the in situ metabolic activity of microorganisms (Murphy and Hostetler 1989). Pressure measurements provide data related to depth of water. Physical parameter sensors available from commercial sources are not listed in this report. Various $\mathrm{pH}$ sensors are, however, included.

Most of the inorganic and organic chemicals chosen for in situ sensor development are those contaminants that are listed under various federal regulations concerning hazardous waste materials, groundwater contamination, and drinking water. It is these types of sensor technologies that are the primary focus of this report. Most of these are under research and development, and a few are commercially available. The applicable regulations and the chemical constituents associated with them are discussed in the subsequent sections. 


\section{Safe Drinking Nater Act}

The Safe Drinking Water Act (SDWA) of 1974 (42 USC $300 \mathrm{f}$ ) was created to protect groundwater, which is a main source of drinking water, from contamination by organic and inorganic chemicals, radionucleotides, and microorganisms (Walker 1989).

The SDWA Amendments of 1986 (PL 99-339) directed the U.S. Environmental Protection Agency (EPA) to establish a drinking water priority list of contaminants (DWPL) based on a contaminant's occurrence in drinking water, its adverse health effects, and the availability of data to set regulated levels. The list is to be updated every three years. The first list was published in January, 1988 and contained 53 contaminants and contaminant groups. The chemicals listed on the DWPL were taken from various sources including the original list of contaminants regulated under the SDWA, disinfectants and disinfection by products, the first 50 chemicals regulated under the superfund Amendments and Reauthorization Act (SARA) of 1986, unregulated volatile organic chemicals to be monitored under the SDWA, and pesticides from th, National Pesticide survey (Cotruvo and Regelski 1989). The second list, which appeared in January 1991, contains 77 contaminants and contaminant groups (40 CFR 141, 1991). The 1991 drinking water priority list is provided in Table 1.

The Safe Drinking Water Act Amendments of 1986 also directed the EPA to set enforceable maximum contaminant levels (MCLs) and nonenforcable recommended maximum contaminant levels (RMCLs), later designated maximum contaminant-level health goals (MCLGs) for 83 contaminants in three phases by June 1989 under the National Primary Drinking Water Regulations (NPDWR) (40 CFR 141, 1986). At least 25 of the regulated contaminants from the DWPI must have regulations promulgated within 36 months after publication of the DWPL. In July 1987, EPA promulgated regulations for 8 volatile organic compounds and 51 unregulated organic compounds for which monitoring is required (40 CFR 141 and 142, 1987). From a list proposed in May 1989, MCLs and MCLGs were set for 26 synthetic organic and seven inorganic contaminants on the DWPL on January 30, 1991 (40 CFR 141-143, 1991). Also included was a list of 110 organic and 6 inorganic unregulated contaminants for which monitoring is required. Regulations for lead and copper were promulgated on June 7, 1991 (40 CFR 141 and $142,1.991)$. 
The inorganic chemicals regulated under the NPDWRs are listed in Table 2 along with their final or proposed MCLs and MCLGs, where established. Table 2 also lists inorganic chemicals regulated under the National Secondary Drinking Water Regulations (NSDWR) (40 CFR 143, 1986). These levels are not enforceable but are meant to provide additional guidance when evaluating drinking water sources.

The regulated organic chemicals include volatile organic chemicals (VOCs) used widely as unleaded gasoline additives, cleaning solutions, and solvents. They are commonly detected in drinking water from groundwater contamination sources. Over one-half of the synthetic organic chemicals regulated are pesticides. They are inherently toxic and may be either applied directly to water or contribute to groundwater contamination through runoff (Cotruvo and Regelski 1989). Table 3 lists the organic chemicals regulated under the NPDWRs, their MCIs and MCLGs .

These lists are somewhat dynamic as the regulations are developed and anended and new compounds are added. For example, in 1992, silver will be removed from the primary standards list and put on the secondary list. The point to be made is that there is a large number of contaminants of concern for the monitoring of drinking water, and this number will increase significantly in future years. Analytical costs will increase significantly also.

\section{Resource Conservation and Recovery Act}

The Resource Conservation and Recovery Act (RCRA) of 1976 (PL 94-580) completely revamped the Solid Waste Disposal Act of 1965. RCRA was designed to provide assurance through federal regulations that solid waste materials are managed in an environmentally sound manner from cradle to grave. In 1984, RCRA was amended under the Hazardous and Solid Waste Amendments to the Resource Conservation and Recovery Act (PL 98-616). The Amendments added Subtitle I requiring the EPA to develop regulations for the control of underground storage tanks. Under RCRA regulations, solid waste materials must first be classified as hazardous or nonhazardous according to established criteria. RCRA currently is in the process of reauthorization, and many significant changes are possible.

Two types of wastes are defined as hazardous under RCRA: the characteristic wastes and the listed wastes. A characteristic 
hazardous waste exhibits one or more of the characteristics of ignitability, corrosivity, reactivity, or toxicity. Toxicity is measured by the toxicity characteristic leaching procedure (TCLP), which simulates the environment of a municipal landfill. Table 4 lists the leachate analytes and levels of interest. The metals listed in Table 4 are commonly called the eight RCRA metals. The EPA also has designated 450 listed hazardous wastes. These are wastes that exhibit one of the above characteristics, are acute hazardous wastes known to be very toxic, or wastes that contain a toxic constituent listed in Appendix VIII of 40 CFR 261 (1990).

Section 3004 of RCRA requires owners and operators of hazardous waste treatment, storage, and disposal facilities to comply with EPA standards "necessary to protect human health and the environment" (42 USC 6924, 1980). The EPA released standards to protect groundwater from contamination by regulated units in 1982. At that time, owners or operators of regulated units were required to monitor groundwater at specified times and determine if any constituerts listed in Appendix VIII were present. Appendix VIII is a compilation of several other lists and is meant to include a very broad range of chemicals. It serves its purpose for listing wastes as hazardous but is not applicable to groundwater assessments in many situations. Many of the chemicals listed in Appendix VIII are not stable in water, and analytical screening methods for all the chemicals on the list do not exist. As a result of these problems, the EPA published the Appendix IX Iist of chemicals (40 CFR 264 and 270, 1987). This list of chemicals will be required for groundwater monitoring at RCRA land-based hazardous waste disposal site.

As part of the permitting procedure, owners and operators of regulated facilities are required to conduct one of threa types of groundwater monitoring programs: (1) a detection monitoring program, (2) a compliance monitoring program, and (3) a corrective action program. A detection monitoring program is designed to determine whether or not a regulated unit is leaking hazardous wastes into the underlying groundwater. Certain indicator parameters such as total organic carbon, total organic halogens, or other constituents specified in the facility permit are monitored to detect any significant increase in concentrations above the background levels in the groundwater. If any of the hazardous constituents listed in Appendix IX are detected in groundwater in the uppermost aquifer underlying a regulated unit at levels above the background levels established in the facility permit, the owner or operator must institute a 
compliance monitoring program (Quarles 1982). A compliance monitoring program consists of two parts. First, the regional EPA administrator will establish a groundwater protection standard for the facility that is specified in the permit for the unit. A program will then be instituted to monitor groundwater for hazardous constituent levels above those specified in the permit. Permit levels are set by the EPA administrator based on the background levels of the constituent in the groundwater, the MCLs listed in the NPDWRs, and/or an alternate concentration limit approved by the EPA (Quarles 1982).

\section{Water Quality Act}

The Water Quality Act of 1987 (PL 100-4) amended the Clean Water Act of 1977 and the Federal Water Pollution Control Act of 1972. The main provision of the Water Quality Act was to establish a permit system regulating the discharge of pollutants into navigable waterways. The National Pollution Discharge Elimination system (NPDES) prohibits the discharge of any pollutant into a navigable waterway unless authorized by a permit. In general, every applicant for an NPDES permit must provide quantitative data on proposed effluents for the following parameters: biological oxygen demand (BOD), chemical oxygen demand (COD), total organic carbon (TOC), total suspended solids (TSS), ammonia (as N), temperature, and $\mathrm{pH}$. In addition, an applicant may be required to submit additional quantitative data on effluent characteristics based on the type of industry the effluent results from. Specific requirements for primary industry categories are outlined in 40 CFR 122 (1990). Under the water Quality Act, the EPA is also required to issue effluent guidelines b. sed on the "best available control technology economically achievable" for 125 priority toxic pollutants. The priority pollutants currently regulated by the EPA are listed in Table 5 (U.S. EPA, 1991). The numbers assigned to the chemicals in Table 5 are from the EPA reference.

Comprohensive invironmental Response, Compensation, and Iiability Act

The Comprehensive Environmental Response, Compensation, and Liability Act (CERCLA) of 1980, otherwise known as Superfund, was created to expedite the cleanup of groundwater contaminated by closed or abandoned dump sites. The Superfund Amendments and Reauthorization Act (SARA) was signed into law in October 1986. These amendments increased Superfund's revenues from $\$ 1.6$ to 
$\$ 8.5$ billion, and strengthened EPA's authority to conduct both short-term and long-term remedial and enforcement actions.

Chemical analyses for superfund site activities principally involve the EPA Contract Laboratory Program (CLP). The analyte list is called the target-compound list, or TCL. This consists of 33 volatile organic compounds, 64 semivolatile organics, and 28 pesticides/PCBs, which comprise the priority pollutant list (Table 5). Also included are 23 metals (Table 6) and cyanide (U.S. EPA 1988). A National Contingency Plan was created to regulate the methods for cleanup projects. Throuydout the cleanup process of such sites, it is desirable to monitor selected parameters in the groundwater using remote chemical sensing technology. This is a more cost-effective approach than collecting samples and conducting laboratory analyses. Project cleanup discharge into a stream or other discharge routes will fall under NPDES permits or other applicable regulations.

\section{The Ongaturated zone}

The unsaturated zone, or vadose zone, deserves some mention. This is the area above the groundwater table. Actually, soil systems are much more complicated than the simplified division into saturated and unsaturated regimes implies (Jenny 1980). Major contaminants of concern include volatile organic chemicals, such as hydrocarbons or fuels from spills or leaking underground storage tanks, and spilled degreasing solvents such as trichloroethylene (Schuring 1989). Pesticides, herbicides, fertilizer components, or waste chemicals present in soils can enter the groundwater system by migrating through the unsaturated zone (Dragun et al. 1984). Mapping the presence of such materials can be accomplished rapidly by using probes equipped with appropriate sensor devices. For example, a penetrometer system using a 1.25 -inch probe is currently in use by the U.S. Department of Defense (Wynne 1991). This avoi.ds the necessity of drilling wells and results in about one-tenth the cost. The probe is pressed into the soil to a depth $E$ up to 70 feet with a hydraulic system attached to a 20-ton truck. The only chemical sensor developed for this probe, so far, is a laser-induced fluorescence device equipped with a sapphire window in the probe and fiber optics for the mapping of aromatic hydrocarbons from fuel spills (Lieberman et al. 1991). More sensors are needed for use with this system.

Other devices, which are commercially available as systems, include sensors placed in the vicinity of underground storage 
tanks or industrial processes to trigger an alarm in the event of a spill.

\section{Fvaluation of Sansor Characteristics}

The main considerations in determining a sensor's compatibility with monitoring needs are detectability and sensitivity. The sensor must be able to measure a contaminant of interest at a level consistent with regulatory needs at a site. If these two criteria are met satisfactorily, other characteristics of the system should be evaluated such as (1) selectivity for the contaminants of interest, (2) interference problems, (3) response time, (4) reversibility, (5) ease of operation in the field, and (6) suitability for in situ detection.

Selectivity and interferences are closely related when evaluating sensor characteristics. The sensor will be of little use for determining specific contaminants if interferences from other compounds mask the contaminant of interest. However, a sensor need not be selective for one specific component of interest if other potential interferences are known to be absent.

Response time is an important consideration when evaluating sensor systems for environmental work. Reversibility is an important consideration for remote in situ work. A sensor must be reversible to be operated remotely, although this is not a necessity for field screening applications.

A sensor's suitability for field use is dependent on several criteria. A sensor designed for field use should be rugged and fabricated to withstand considerable physical shock as well as various temperature regimes. The sensor should be fairly stable, as calibration of in situ systems is generally more difficult. It is advantageous to design a sensor system for field use to be as portable as possible, and the power requirements of a system are important considerations, especially if the field site is very remote (Murphy and Hostetler 1989). 
The appendices of this report consist of individual pages, each providing information on a particular sensor. Although every effort was made to provide accurate and complete information, the specific reference should be checked by individuals interested in further pursuing a particular technology. In cases where the mode of detection involves monitoring changes in color intensity, the terms absorbance and reflectance for the detection principle are generally used as in the original references. As noted by seitz (1984), the distinction is not always made correctly in the literature.

Appendix A lists the organic compound sensors. It contains 47 entries spanning a wide range of technologies. These include, followed by number of entries, Raman spectroscopy (10), optical fluoresence (10), semiconductor technology (9), optical absorbance or reflectance (9), refractive index changes (5), chemical fuses (2), and one each of electrometric and liquid crystal technology. The sensors measure one or more types of compounds. The type and number include aromatic hydrocarbons (12), chlorinated compounds (7), phenolic compounds (4), pyridinic compounds (4), methane (4), polycyclic aromatic hydrocarbons (3), nitroaromatic compounds (3), aliphatic alcohols (2), and aliphatic hydrocarbons (1). In addition, a list of 16 general-purpose sensors which could measure one or more of the above compound types is included.

Appendix B lists 16 sensors for metals. The technologies include optical fluorescence or fluorescence quenching (9), optical absorbance or reflectance (2), and one each of electrometric, piezoelectric crystal microbalance, photothermal spectroscopy, and surface enhanced Raman spectroscopy (SERS). Many of the sensors can measure more than one metal. The metals and the number of sensors capable of measuring them are magnesium (4), aluminum (3), zinc (3), calcium (2), cadmium (2), copper (2), potassium (2), actinides (2), and one each for beryllium, chromium, cobalt, indium, gallium, iron, and lead.

Appendix $C$ lists 13 sensors, 10 for anions and 3 for cations. The technologies for the anions include optical fluorescence (6), optical absorbance or reflectance (3), and one electrometric. Several of the sensors measure more than one anion. These include iodide (4), bromide (3), chloride (2), carbonate (2), sulfide (2), and one each for fluoride and cyanide. The three cation sensors all measure ammonium. One 
sensor uses optical fluorescence of an indicator and the other two use optical absorbance or reflectance technology.

Appendix D lists $18 \mathrm{pH}$ sensors. The technologies used are optical absorbance or reflectance (9), optical fluorescence (6), and non-standard electrometric (3).

A list of general purpose sensors which are available for a wide variety of applications is provided in Appendix E. Many of these are commercially available with applications support provided by the manufacturer. 


\section{CONCLUSION8}

Information on the state of the art for chemical sensors, both under development and commercially available, has been compiled in a single, comprehensive report. Current environmental regulations involving chemical monitoring and analyses have been summarized. This should be useful for rapidly accessing information and references for site monitoring programs, technology licensing, and research design. 


\section{ACRTOWLDGWMETS}

The authors wish to acknowledge the many people whose contributions were essential to this work. These include Val Chilson (librarian), Marie Hauff (typing), Jeanne DeVries and Casey Horner (data input), and Judi Diamond (editing). Also helpful were consultations with Dr. Dottie Lane and Dr. John Nordin (Western Research Institute), Dr. Keith Carron and Dr. Tom Edgar (University of Wyoming), and Bob Kamensky and Gina Bonner Smith (Sorrento Electronics). Funding for this study was provided by the U.S. Department of Energy under cooperative agreement number $\mathrm{DE}-\mathrm{FC} 21-86 \mathrm{MC} 11076$ and support from sorrento Electronics.

\section{DISCIAIMAR}

Mention of specific brand names or models of equipment is for information only and does not imply endorsement of any particular brand. 


\section{RERTRHCES}

40 CFR 122, 1990, National Pollutant Discharge Elimination System, Federal Register, November 16, 48062.

40 CFR 141, 1986, National Primary Drinking Water Regulations, Federal Reqister, July 3, 24328.

40 CFR 141, 1991, Priority List of Substances Which May Require Regulation Under the Safe Drinking Water Act, Federal Register, January 14, 1470-1474.

40 CFR 141 and 142, 1987, National Primary Drinking Water Regulations--Synthetic Organic Chemicals; Monitoring for inregulated Contaminants; Final Rule, Federal Register, July $8,25690-25717$.

40 CFR 141 and 142, 1991, Maximum Contaminant Level Goals and National Drirking Water Regulations for Lead and Copper; Final Rule, Federal Register, June 7, 26460-26564.

40 CFR 141, 142, and 143, 1991, National Primary Drinking Water Regulations, Final Rule, Federal Register, January 30, 35.253597 .

40 CFR 143, 1986, National Secondary Drinking Water Regulations, Federal Register, July 3, 24328.

40 CFR 261, 1990, Identification and Listing of Hazardous Waste, Federal Register, Novernber 13, 47329-47334.

40 CFR 264 and 270, 1987 List (Phase 1) of Hazardous Constituents for Ground-Water Monitoring; Final Rule (Appendix IX), Federal Register, July 9, 25942-25953.

42 USC 300f, 1974, The Safe Drinking Water Act, Title 42, United States Code, Part $300 f$.

42 USC 6924, 1980, RCRA Subtitle C, Part 3004, Title 42, United States Code, Part 3004 .

Cotruvo, J.A., and M. Regelski, 1989, National Primary Drinking Water Regulations for Volatile Organic Chemicals, in Calabrese, E.J., C.E. Gilbert, and, H. Pastides, eds., Safe Drinking Water Act. Lewis, Chelsea, MI, 29-34. 
Dragun, J., A.C. Kuffner, and R.W. Schneiter, 1984, Transport and Transformation of Organic Chemicals, Chemical Engineering, November 26: 65-70.

Eccles, L.A., S.J. Simon, and S.M. Klainer, 1987, In Situ Monitoring at Superfund Sites with Fiber Optics, EPA R\&D Report EPA/600/X-87/156, Environmental Monitoring systems Laboratory, Las Vegas, NV.

Janata, J., 1989, Principles of Chemical Sensors. Plenum Press, New York, N1, 55-80.

Jenny, H., 1980, The Soil Resource. Springer-Verlag, New York, NY, 34-37.

Lieberman, S.H., G.A. Theriault, P.G. Malone, S.S. Cooper, and P.W. Lurk, 1991, Rapid, Subsurface, In Situ Field Screening of Petroleum Hydrocarbon Contamination Using Laser Induced Fluorescence Over Optical Fibers, Proc. Second International Symposium for Field Screening Methods for Hazardous Wastes and Toxic Chemicals, U.S. EPA.

Murphy, E.M., and D.D. Hostetler, 1989, Evaluation of Chemical Sensors for In Situ Groundwater Monitoring at the Hanford Site, Richland, WA, DOE Report DOE/DE/ACO6-76RLO 1830.

Nielsen, D.M., ed., 1991, Practical Handbook of Ground-Water Monitoring. Lewis, Chelsea, MI.

PL 94-580, 1976, Resource Conservation and Recovery Act of 1976, Federal Public Law 94-580, October 31 .

PL 98-616, 1984, The Hazardous and Solid Waste Amendments of 1984, Federal Public Law 98-616, November 8.

PL 99-339, 1986, The Safe Drinking Water Act Amendments of 1986, Federal Public Law 99-339, June 19.

PL 100-4, 1987, The Water Quality Act, Federal Public Law 100-4.

Quarles, J., 1982, Eederal Regulation of hazardous Wastes: A Guide to RCRA. The Environmental Law Institute, Washington, DC, $229 \mathrm{p}$.

Schuring, D.C., 1989, Soil Gas Testing, Hazmat World, August, 36-39. 
Seitz, W.R., 1984, Chemical Sensors Based on Fiber Optics, Anal. Chem. $56(1): 17 \mathrm{~A}-34 \mathrm{~A}$.

Seitz, W.R., 1988, Chemical Sensors Based on Immobilized Indicators and Fiber Optics, CRC Critical Reviews in Analytical Chemistry, 19(2): 135-173.

Stetter, J.R., 1984, Electrochemical Sensors, Sensor Arrays, and Computer Algorithms, in Schuetzle, D. and R. Hammerle, eds; Fundamentals and Applications of Chemical Sensors. American Chemical Society Symposium Series, Washington, DC, 299-308.

U.S. EPA, 1988 Contract Laboratory Program Statement of Work for Inorganics Analysis, Multi Media Multi-Concentration sow No. 788 , July.

U.S. EPA, 1991 Contract Laboratory Program Statement of Work for Organic Analysis, Multi Media Multi-Concentration.

Walker, B., 1989, Achieving Safe Drinking Water: Summary and Recommendations, in Calabrese, E.J., C.E. Gilbert and, H. Pastides, eds., Safe Drinking Water Act. Lewis, Chelsea, MI, 1 .

Wynne, D.J., 1991, Department of Defense Field Screening Methods Requirements in the Installation Restoration Program, Proc. Second International Symposium for Field Screening Methods for Hazardous Wastes and Toxic Chemicals, U.S. EPA.

Zhujun, Z., J.L. Mullin, J.L., and W.R. Seitz, W.R., 1986, Optical Sensor for Sodium Based on Ion-Pair Extraction and Fluorescence. Anal. Chim. Acta, 184: 251-258. 
Table 1. 1991 Dxinking Water Priority List

\begin{tabular}{|c|c|}
\hline Inorganics & Chlorination/chloroamination \\
\hline & by-products such as haloacetic \\
\hline Aluminum & acids, haloketones, ohloral \\
\hline Boron & hydrate, $M X-12$ [3-chloro-4- \\
\hline Chloramines & (dichloromethyl)-5-hydroxy- \\
\hline Chlorate & $2(5 \mathrm{H})$-furanone], and \\
\hline Chlorine & $\mathrm{N}$-organochloramines \\
\hline Chlorine dioxide & Chloroethane \\
\hline Chlorite & Chloroform \\
\hline Cyanogen chloride & Chloromethane \\
\hline Hypochlorite ion & Chloropicrin \\
\hline Manganese & o-Chlorotoluene \\
\hline Molybdenum & Dibromoacetonitrile \\
\hline strontium & Dibromochloromethane \\
\hline Vanadium & Dibromomethane \\
\hline zinc & Dichloroacetonitrile \\
\hline & 1,3-Dichlorobenzene \\
\hline Pesticides & Dichlorodifluoromethane \\
\hline & 1,1-Dichloroethane \\
\hline Asulam & 2,2-Dichloropropane \\
\hline Bentazon & 1,3-Dichloropropane \\
\hline Bromacil & 1,1-Dichloropropene \\
\hline Cyanazine & 1,3-Dichloropropene \\
\hline Cyromazine & 2,4-Dinitrophenol \\
\hline DCPA (and its acid & 2,4-Dinitrotoluene \\
\hline metabolites) & 2,6-Dinitrotoluene \\
\hline Dicamba & 1,2-Diphenylhydrazine \\
\hline Ethylenethiourea & Fluorotrichloromethane \\
\hline Fomesafen & Hexachlorobutadiene \\
\hline Lactofen/Acifluorfen & Hexachloroethane \\
\hline Metalaxyl & Isophorone \\
\hline Methomyl & Methyl ethylketone \\
\hline Metolachlor & Methyl isobutylketone \\
\hline Metribuzin & Methyl-t-butylother \\
\hline Parathion degradation & Naphthalene \\
\hline product (4-nitrophenol) & Nitrobenzene \\
\hline Prometon & Ozone by-products such as \\
\hline $2,4,5-T$ & aldehydes, epoxides, \\
\hline Thiodicarb & peroxides, nitrosamines, \\
\hline Trifluralin & bromate, iodate \\
\hline & $1,1,1,2$-Tetrachloroethane \\
\hline Synthetic Organic Chemicals & $1,1,2,2$-Tetrachloroethane \\
\hline & Tetrahydrofuran \\
\hline Acrylonitrile & Trichloroacetonitrile \\
\hline Bromobenzene & $1,2,3$-Trichloropropane \\
\hline Bromochloroacetonitrile & \\
\hline Bromodichloromethane & Microorganisms \\
\hline Bromoform & \\
\hline & Crytosporidum \\
\hline
\end{tabular}


Table 2. Inorganic Chemical Govarned onder the National Primary and secondery Drinking Water Regulations

\section{Primary Regulations:}

$\begin{array}{lll}\text { Arsenic } & 0.05 & \mathrm{~N}^{\mathrm{a}} \\ \text { Asbestos } & 7 \text { million fibers/L } & 7 \text { million fibers/L } \\ \text { Barium } & 2 & 2 \\ \text { Cadmium } & 0.005 & 0.005 \\ \text { Chromium } & 0.1 & 0.1 \\ \text { Copper } & \text { Treat if } \geq 1.3 \mathrm{mg} / \mathrm{L} & 1.3 \\ \text { Lead } & \text { Treat if } \geq 0.015 \mathrm{mg} / \mathrm{L} & \text { Zero } \\ \text { Fluoride } & 4 & 4 \\ \text { Mercury } & 0.002 & 0.002 \\ \text { Nitrateb } & 10 \text { (as N) } & 10 \text { (as N) } \\ \text { Nitrite } & 1 \text { (as N) } & 1 \text { (as N) } \\ \text { Selenium } & 0.05 & 0.05\end{array}$

Secondary Regulations:

$\begin{array}{lll}\text { Aluminum } & 0.05-0.2 & \mathrm{~N} \\ \text { Chloride } & 250 & \mathrm{~N} \\ \text { Fluoride } & 2.0 & \mathrm{~N} \\ \text { Iron } & 0.3 & \mathrm{~N} \\ \text { Manganese } & 0.05 & \mathrm{~N} \\ \text { Silver } & 0.1 & \mathrm{~N} \\ \text { Sulfate } & 250 & \mathrm{~N} \\ \text { Zinc } & 5.0 & \mathrm{~N}\end{array}$

a MCLG for total nitrate and nitrite is $10 \mathrm{mg} / \mathrm{L}$ (as $\mathrm{N}$ )

b MCLG not established 


\section{Table 3. Organic Chamicals Governad Onder the National Primary Drinking Water Regulatione}

Contaminant MCL, mg/L MCLG, mg/L

Volatile Organic Chemicals

$\begin{array}{lll}\text { Benzene } & 0.005 & \text { Zero } \\ \text { Carbon tetrachloride } & 0.005 & \text { Zero } \\ \text { o-Dichlorobenzene } & 0.6 & 0.6 \\ \text { p-Dichlorobenzene } & 0.075 & 0.075 \\ 1,2 \text { Dichloroethane } & 0.005 & \text { Zero } \\ 1,1 \text { Dichloroethylene } & 0.007 & 0.007 \\ \text { C-1,2 Dichloroethylene } & 0.007 & 0.007 \\ \text { t-1,2 Dichloroethylene } & 0.1 & 0.1 \\ \text { 1,2 Dichloropropane } & 0.005 & \text { Zero } \\ \text { Ethylbenzene } & 0.7 & 0.7 \\ \text { Monochlorobenzene } & 0.1 & 0.1 \\ \text { Styrene } & 0.1 & 0.1 \\ \text { Tetrachloroethylene } & 0.005 & \text { Zero } \\ \text { Toluene } & 1 & 1 \\ \text { 1,1,1 Trichloroethane } & 0.2 & 0.2 \\ \text { Trichloroethylene (TCE) } & 0.005 & \text { Zero } \\ \text { Trihalomethanes } & 0.1 & \mathrm{~N} \\ \text { Vinyl chloride } & 0.002 & \text { zero } \\ \text { Xylenes (total) } & 10 & 10\end{array}$

Synthetic Organic Chemicals

\begin{tabular}{|c|c|c|c|}
\hline Acrylamide & Treatment & Techniqueb & Zero \\
\hline Alachlor & 0.002 & & Zero \\
\hline Aldicarb & 0.003 & & 0.001 \\
\hline Aldicarb sulfone & 0.003 & & 0.002 \\
\hline Aldicarb sulfoxide & 0.003 & & 0.001 \\
\hline Atrazine & 0.003 & & 0.003 \\
\hline Carbofuran & 0.04 & & 0.04 \\
\hline Chlordane & 0.002 & & $z \in x_{0}$ \\
\hline 1,2-Dibromo-3-chloropropane (DBCP) & 0.0002 & & zero \\
\hline $2,4-D$ & 0.07 & & 0.07 \\
\hline Endrin & 0.0002 & & $\mathbf{N}$ \\
\hline Epichlorohydrin & Treatment & Technique & Zero \\
\hline Ethylene dibromide (EDB) & 0.00005 & & Zero \\
\hline Heptachlor & 0.0004 & & Zero \\
\hline Heptachlor epoxide & 0.0002 & & zero \\
\hline Lindane & 0.0002 & & 0.0002 \\
\hline Methoxychlor & 0.04 & & 0.04 \\
\hline Polychlorinated biphenyls & 0.0005 & & Zero \\
\hline Pentachlorophenol & 0.001 & & zero \\
\hline Toxaphene & 0.003 & & Zero \\
\hline $2,4,5$-TP (Silvex) & 0.05 & & 0.05 \\
\hline
\end{tabular}

a MCLG not established

b No analytical methods available; treatment techniques used 
Table 4.TCLP Analytes and Ragulatory Iimits in $\mathrm{mg} / \mathrm{I}$ for Extracts

Metals

Arsenic

Barium

Cadmium

Chromium

Lead

Mercury

Selenium

Silver

5.0
100
1.0
5.0
5.0
0.2
1.0
5.0

\section{Volatile Organics}

$\begin{array}{lr}\text { Benzene } & 0.5 \\ \text { Carbon tetract.loride } & 0.5 \\ \text { Chlorobenzene } & 100 \\ \text { Chloroform } & 6.0 \\ 1,2-\text { Dichloroethane } & 0.5 \\ 1,1-D i c h l o r o e t h y l e n e & 0.7 \\ \text { Methyl ethyl ketone } & 200 \\ \text { Tetrachloroethylene } & 0.7 \\ \text { Trichloroethylene } & 0.5 \\ \text { Vinyl chloride } & 0.2\end{array}$

Semi-volatile Organics

o-Cresol

m-Cresol

p-Cresol

1, 4-Dichlorobenzene

2, 4-Dinitrotoluene

Hexachlorobenzene

Hexachloroethane

Nitrobenzene

Pentachlorophenol

Pyridine

2, 4, 5-Trichlorophenol

2, 4, 6-Trichlorophenol
200

200

200

7.5

0.13

0.13

3.0

2.0

100

5.0

400

2.0

\section{Pesticides/Herbicides}

\section{Chlordane}

2, 4-D

Endrin

Heptachlor (and its hydroxide)

Lindane

ivethoxychlor

Toxaphene

$2,4,5-\mathrm{TP}$ (Silvex)

$$
\begin{aligned}
& 0.3 \\
& 10 \\
& 0.02 \\
& 0.008 \\
& 0.4 \\
& 10 \\
& 0.5 \\
& 1.0
\end{aligned}
$$


Table 5. Priority Pollutant List

\begin{tabular}{|c|c|c|c|}
\hline Number & Chemical Name & Number & Chemical Name \\
\hline 1 & Chloromethane & 64 & 2,6 -Dinit rotoluene \\
\hline 2 & Bromomethane & 65 & $3-\mathrm{N} 1$ troan111ne \\
\hline 3 & vinyl chlorlde & 66 & Acenaphthene \\
\hline 4 & Chloroethane & 67 & 2,4-Din1t rophenol \\
\hline 5 & Methylene chlorlde & 68 & 4-Nit rophenol \\
\hline 6 & Acetone & 69 & D1benzofuran \\
\hline 7 & Carbon disulfide & 70 & $2,4-D$ in 1 trotoluene \\
\hline 8 & 1,1-D1chlorsethene & 71 & Dlethylphthalate \\
\hline 9 & 1,1-D1chloroethane & 72 & 4-Chlorophenyl-phenylether \\
\hline 10 & 1,2 -Dlchloroethene (total) & 73 & Fluorene \\
\hline 11 & chloroform & 74 & $4-N 1 t \operatorname{roan} 111$ ne \\
\hline 12 & 1,2 -D1ehloroethane & 75 & $4,6-D$ In 1 t ro-2-methy 1 phenol. \\
\hline 13 & 2-But anone & 76 & N-N1t rosodiphenylamine \\
\hline 14 & $1,1,1-$ Tr1chloroethane & 77 & 4-Bromopheny 1 -phenylether \\
\hline 15 & Carbon tetrachlorlde & 78 & Hexachlorobenzene \\
\hline 16 & Bromodichloromethane & 79 & Pentachlorophenol \\
\hline 17 & 1,2-D1chloropropane & 80 & Phenanthrene \\
\hline 18 & c1s-1.3-D1chloropropene & 81 & Anthracene \\
\hline 19 & Trichloroethene & 82 & Carbazole \\
\hline 20 & Dibromoch loromethane & 83 & D1-n-Butylphthalate \\
\hline 21 & $1,1,2$-Trichloroethane & 84 & Fluoranthene \\
\hline 22 & Benzene & 85 & Pyrene \\
\hline 23 & trans-1,3-D 1 chloropropene & 86 & Butylbenzylphthalate \\
\hline 24 & Bromoform & 87 & $3,3^{\prime}$-D1ehlorobenzldine \\
\hline 25 & 4-Methy 1-2-Fent anone & 88 & Benzo [a] anthracene \\
\hline 26 & 2-Hexanone & 89 & Chrysene \\
\hline 27 & Tetrachloroethene & 90 & bis (2-Ethylhexy1) phthalate \\
\hline 28 & Toluene & 91 & Di-n-octylphthalate \\
\hline 29 & $1,1,2,2$-Tet rach loroethane & 92 & Benzo[b]flioranthene \\
\hline 30 & Chlorobenzene & 93 & Benzo(k)fluoranthene \\
\hline 31 & Ethylbenzene & 94 & Benzola]pyrene \\
\hline 32 & styrene & 95 & Indeno $[1,2,3-c, d]$ pyrene \\
\hline 33 & xylenes (total) & 96 & Dlbenz $[a, h]$ anthracene \\
\hline 34 & Phenol & 97 & Benzolg, $h, 1]$ perylene \\
\hline 35 & bis $(2-$ Chloroethyl)ether & 98 & alpha-BHC \\
\hline 36 & 2-Chlorophenol & 99 & beta-BHC \\
\hline 37 & 1,3-D1ehlorobenzene & 100 & delta-BHC \\
\hline 38 & $1,4-D 1 c h 10$ robenzene & 101 & gamma-BHC (LIndane) \\
\hline 39 & $1,2-D 1$ chlorobenzene & 102 & Heptachlor \\
\hline 40 & 2-Methylphenol & 103 & Aldrin \\
\hline 41 & $2,2^{\prime}$-oxyb1s (1-Chloropropane) & 104 & Heptachl-r epoxide \\
\hline 42 & 4-Methylphenol & 105 & Endosulf $\doteq \mathrm{n}$ I \\
\hline 43 & $N-N 1$ troso-d1-n-propylamine & 106 & Dieldrin \\
\hline 44 & Hexachloroethane & 107 & $4,4^{\prime}-D D E$ \\
\hline 45 & Nitrobenzene & 108 & Endrin \\
\hline 46 & Isophorone & 109 & Endosulfan II \\
\hline 47 & z-N1trophenol & 110 & $4,4^{\prime}-D D D$ \\
\hline 48 & 2,4-Dimethylphenel & 111 & Ensisulfan sulfate \\
\hline 49 & b1s (2-Chloroethoxy) methane & 112 & $4,4^{\prime}-D D T$ \\
\hline 50 & 2, 4-D1chlorophenol & 113 & Methoxychlor \\
\hline 51 & $1,2,4-\operatorname{Tr} 1$ chlorobenzene & 114 & Endrin ketone \\
\hline 52 & Waphthalene & 115 & Endrin aldehyde \\
\hline 53 & 4 -Chloreanaline & 116 & alpha-Chlordane \\
\hline $5^{4}$ & Hexachlorobut adlene & 117 & gamma-Chlordane \\
\hline 55 & 4-Chloro-3-methyl Fhenol & 118 & Toxaphene \\
\hline 56 & 2-Methylnaphthalene & 119 & Aroclor -1016 \\
\hline 57 & Hexachlorocyclofentadiene & 120 & Aroclor-1221 \\
\hline 58 & $2,4,6-\operatorname{Tr} 1$ chlorophenol & 121 & Aroclor -1232 \\
\hline 59 & $2,4,5-T r 1=h$ lorophenol & 122 & Aroclor -1242 \\
\hline 60 & 2 -Chloronaphthalene & 123 & Aroclor 1248 \\
\hline 51 & $2-11 \operatorname{toan} 11 \mathrm{n} \in$ & 124 & Aroclor 1254 \\
\hline 52 & Dimethylpht halate & 125 & Aroclor 1260 \\
\hline 63 & Acenaphthylene & & \\
\hline
\end{tabular}


Table 6. Contract Laboratoxy Program Baxardous subatanca list Matal:

\begin{tabular}{ll}
\hline & Magnesium \\
Antimony & Manganese \\
Arsenic & Mercury \\
Barium & Nickel \\
Beryllium & Potassium \\
Cadmium & Selenium \\
Calcium & Silver \\
Chromium & Sodium \\
Cobalt & Thallium \\
Copper & Vanadium \\
Iron & Zinc \\
Lead & \\
\hline
\end{tabular}


APPELDIX $A$

Organic Compound Sensora 
COMPOUND CLASS DETECTED: Aliphatic AlCohol

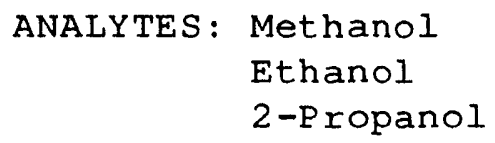

MANUFACTURER/DEVELOPER: University of Warwick Dept. of Engineering Coventry CV4 7AL JK

DETECTION METHOD: Tin oxide semiconductor sensing element

SUPPORT EQUIPMENT: Taguchi gas sensors, potentiometers

CAPABILITIES: VAPOR: Y LIQUID: $\mathrm{N}$ REVERSIBLE : ?

STATE OF DEVELOPMENT: Lab research

REFERENCES: Shurmer, H.V., J.W. Gardner, and P. Corcoran, 1990, Intelligent Vapour Discrimination Using a Composite 12-Element Sensor Array. Sensors and Actuators, B1: 256-260. 
COMPOUND CLASS DETECTED: Aliphatic and aromatic hydrocarbon

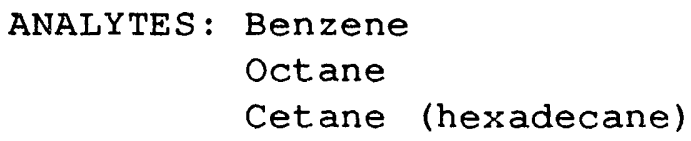

DETECTION METHOD: Chemical fuse triggers mechanical switch

SUPPORT EQUIPMENT: Remote-station alarm unit

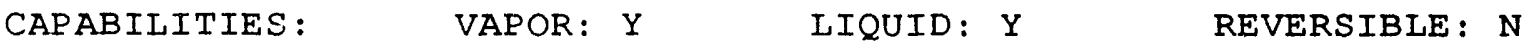

STATE OF DEVELOPMENT: Commercial

REFERENCES: In-Situ, Inc., 1990, Low-Cost UST Monitoring, Manufacturer's Literature, Selection Chart. 
COMPOUND CLASS DETECTED: Aromatic and chlorinated

ANALYTES: Various organics

Gasoline and fuels

DETECTION LIMIT RANGE: $\%$ level

MANUFACTURER/DEVELOPER: Raychem Corporation 300 Constitution Drive

Menlo Park, CA 94025-1164 USA

DETECTION METHOD: Liquid sensor

CAPABILITIES: VAPOR: Y LIQUID: $N$ REVERSIBLE: $N$

STATE OF DEVELOPMENT: Commercial

REFERENCES: Raychem Corporation, 1991, TT500 Sensing Cables, Manufacturer's Literature. 
COMPOUND CLASS DETECTED: Aromatic and chlorinated, volatile

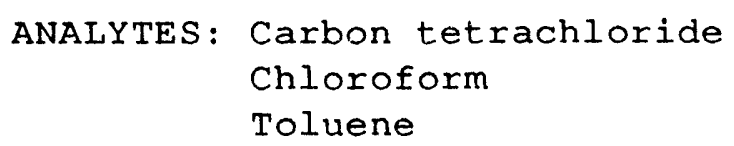

MANUFACTURER/DEVELOPER: University of Washington Dept. of Chemistry BG-10

Seattle, WA 98195 USA

DETECTION METHOD: Evanescent absorbance, FT-NIR

SUPPORT EQUIPMENT: Fiber optic probe, FT-NIR spectrometer, photocell

CAPABILITIES: $\quad$ VAPOR: $N$ LIQUID: $Y$ REVERSIBLE: $Y$

STATE OF DEVELOPMENT: Lab research

REFERENCES: Degrandpre, M.D., and L.W. Burgess, 1990, A FiberOptic ET-NIR Evanescent Field Absorbance Sensor. App. Spec., $44(2): 273-279$. 
COMPOUND CLASS DETECTED: Aromatic and chlorinated, volatile

ANALYTES: Benzene

Chloroform

DETECTION LIMIT RANGE: ppm

MANUFACTURER/DEVELOPER: Monsanto Research Corp.

St. Louis, MO USA

DETECTION METHOD: Color change on liquid crystals measured by absorption spectroscopy

SUPPORT EQUIPMENT: LAmp, spectrometer, wave guide, detector

CAPABILITIES: VAPOR: $Y$ LIQUID: $N$ REVERSIBLE: $Y$

STATE OF DEVELOPMENT: Lab research

REFERENCES: David, D.J., and E.E. Harey, 1977, Organic Vapor Detection with Liquid Crystals. U.S. Pat. $4,040,749$. 
COMPOUND CLASS DETECTED: Aromatic hydrocarbon, volatile

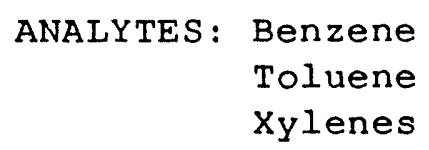

DETECTION LIMIT RANGE: pPm

MANUFACTURER/DEVELOPER: International Sensor Technology 17771 Fitch Street

Irvine, CA 92714 USA

DETECTION METHOD: Solid-state sensor, changes in resistance

SUPPORT EQUIPMENT: Support electronics

CAPABILITIES: $\quad$ VAPOR: $Y$ LIQUID: $N$ REVERSIBLE: $Y$

STATE OF DEVELOPMENT: Commercial

REFERENCES: International Sensor Technology, 1991, Condensed Product Catalog. 
COMPOUND CLASS DETECTED: Aromatic hydrocarbon, volatile

ANALYTES: Benzene

MANUFACTURER/DEVELOPER: University of Utah

Dept. of Engineering

Salt Lake City, UT 84112 USA

DETECTION METHOD: Laser-induced fluorescence

SUPPORT EQUIPMENT: Laser, spectrometer

CAPABILITIES: VAPOR: $N$ LIQUID: $Y$ REVERSIBLE: $Y$

STATE OF DEVELOPMENT: Lab research

REFERENCES: Newby, K., W.M. Reichert, J.D. Andrade, and R.E. Benner, 1984, Remote spectroscopic Sensing of Chemical Adsorption using a Single Multimode Optical Fiber. Applied Optics, 23: 1812-1815. 
COMPOUND CLASS DETECTED: Aromatic hydrocarbon, volatile

ANALYTES: Benzene

DETECTION LIMIT RANGE: ppm

MANUFACTURER/DEVELOPER: University of Wyoming

Dept. of Chemistry

Laramie, WY 82071 USA

DETECTION METHOD: Surface-enhanced Raman spectroscopy

(SERS) of analyte adsorbed on

indicator on silver surface

SUPPORT EQUIPMENT: Laser, monochromator, detector, computer, fiber optics

CAPABILITIES: VAPOR: N LIQUID: $Y$ REVERSIBLE: $Y$

STATE OF DEVELOPMENT: LAb research

REFERENCES: Carron, K.T., and K.I. Mullen, 1991, Surface Enhanced Raman Spectroscopy with Abrasively Modified Fiber Optic Probes. Anal. Chem., in press. 
COMPOUND CLASS DETECTED: Aromatic hydrocarbon, volatile

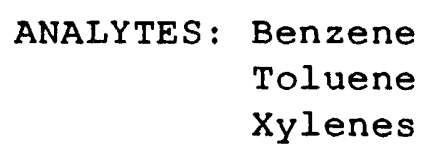

DETECTION LIMIT RANGE: ppb

MANUFACTURER/DEVELOPER: ST\&E, InC.

1214 Concannon Boulevard

Livermore, CA 94550 USA

DETECTION METHOD: Fluorescence of dye attenuated by refractive index changes

SUPPORT EQUIPMENT: Lamp, spectrometer, detector, fiber optics

CAPABILITIES: VAPOR: Y LIQUID: $Y$ REVERSIBLE: $Y$

STATE OF DEVELOPMENT: Lab research

REFERENCES: Klainer, S.M., D.K. Dandge, and K. Goswami, 1988, A Fiber Optic Chemical Sensor for Monitoring Gasoline. U.S. EPA Report 600/X-88/259. 
COMPOUND CLASS DETECTED: Aromatic hydrocarbon, volatile

ANALYTES: Gasoline

MANUFACTURER/DEVELOPER: Fiberchem, InC.

1181 Grier Drive, Suite B

Las Vegas, NV 89119 USA

DETECTION METHOD: Chemical reaction, fluorescence, refractive index change

SUPPORT EQUIPMENT: Argon laser, detector, fiber optics

CAPABILITIES: VAPOR: N LIQUID: $Y$ REVERSIBLE : $Y$

STATE OF DEVELOPMENT: Field tested

REFERENCES: Le Goullon, D., and K. Goswami, 1990, Fiber Optic Refractive Index Sensor Using a Metal Clad. U.S. Pat. 4,929,049. 
COMPOUND CLASS DETECTED: Aromatic hydrocarbon and phenolic

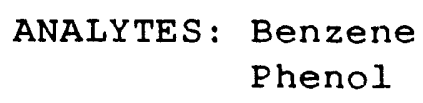

DETECTION LIMIT RANGE: pPb

MANUFACTURER/DEVELOPER: Tufts University

Civil Engineering Dept.

Medford, MA 02155 USA

DETECTION METHOD: Laser-induced fluorescence

SUPPORT EQUIPMENT: Laser, filter, detector, fiber optics

CAPABILITIES: VAPOR: $N$ LIQUID: $Y$ REVERSIBLE: $Y$

STATE OF DEVELOPMENT: Field tested

REFERENCES: Chudyk, W., K. Pohlig, N. Rico, and G. Johnson, 1989, Field Screening for Aromatic Organics Using Laser-Induced Fluorescence and Fiber Optics. First. Annual Field Screening Methods for Hazardous Waste Site Investigations Proceedings, Las Vegas, NV, $\mathrm{EPA} / 600 / \mathrm{D}-89 / 189$. 
COMPOUND CLASS DETECTED: Aromatic hydrocarbon and phenolic

\author{
ANALYTES: Benzene \\ Phenol \\ Nophthalene
}

DETECTION LIMIT RANGE: ppm

MANUEACTURER/DEVELOPER: Oak Ridge National Laboratory

P.O. Box 2008

Oak Ridge, TN 37831-6113 USA

DETECTION METHOD: Second derivative ultraviolet absorption spectroscopy (DUVAS)

SUPPORT EQUIPMENT: UV/VIS spectrophotometer with derivative capability, fiber optics

CAPABILITIES: VAPOR: N LIQUID: $Y$ REVERSIBLE: $Y$

STATE OF DEVELOPMENT: Field tested

REFERENCES: Haas, J.W., III, E.Y. Lee, C.L. Thomas, and R.B. Gammage, 1989, Second-Derivative Ultraviolet Absorption Monitoring of Aromatic Contaminants in Groundwater. First Annual Field Screening Methods for Hazardous waste Site Investigations Proceedings, Las Vegas, NV, EPA/600/D-89/189. 
COMPOUND CLASS DETECTED: Aromatic hydrocarbon and pyridinic

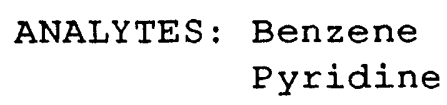

DETECTION LIMIT RANGE: PPb

MANUFACTURER/DEVELOPER: Lawrence Livermore National Laboratory

P.O. Box 808, L-524

Livermore, CA 94550 USA

DETECTION METHOD: Raman spectrosCOPY

SUPPORT EQUIPMENT: Laser, spectrometer, detector, fiber optics

CAPABILITIES: $\quad$ VAPOR: $N$ LIQUID: $Y$ REVERSIBLE: $N$

STATE OF DEVELOPMENT: Lab research

REFERENCES: Myrick, M.L., and S.M. Angel, 1989, Normal and Surface-Enhanced Raman Scattering with Optical Fibers. SPIE Proceedings, Boston, MA, P. 38-48.

Angel, S.M., M.K. DeArmond, K.W. Hanck, and D.W. Wertz, 1984, Computer-Controlled Instrument for the Recovery of a Resonance Raman. Spectrum in the Presence of Strong Luminescence. Anal. Chem., 56: 3000-3001. 
COMPOUND CLASS DETECTED: Chlor: nated, volatile

ANALYTES: $1,1,1$-Trichloroethane

Carbon tetrachloride

DETECTION LIMIT RANGE: ppm

MANUFACTURER/DEVELOPER: Pacific Northwest Laboratory

P.O. Box 999 K6-81

Richland, WA 99352 USA

DETECTION METHOD: Radio frequency-induced helium plasma (RFIHP) optical emisssion spectroscopy

SUPPORT EQUIPMENT: RE generator, spectrometer, detector

CAPABILITIES: $\quad$ VAPOR: $Y$ LIQUID: $N \quad$ REVERSIBLE: $Y$

STATE OF DEVELOPMENT: Lab research

REFERENCES: Olsen, K.B., J.W. Griffin, D.A. NeIson, B.S. Matson, and P.A. Eschbach, 1989, Prototype Design and Testing of Two Fiber-optic spectrochemical Emission Sensors. Eirst Annual Field Screening Methods for Hazardous Waste Site Investigations Proceedings, Las Vegas, NV, EPA/600/D-89/189. 
COMPOUND CLASS DETECTED: Chlorinated, volatile

ANALYTES: Chloroform

DETECTION LIMIT RANGE: ppm

MANUFACTURER/DEVELOPER: LOCkheed-ESC

1050 E.Flamingo, Suite 120

Las Vegas, NV 89119 USA

DETECTION METHOD: Chemical reaction, fluorescence, fiber optics

SUPPORT EQUIPMENT: Laser, spectrometer, detector

CAPABILITIES: VAPOR: $\mathrm{Y}$ LIQUID: $\mathrm{N}$ REVERSIBLE: $\mathrm{N}$

STATE OF DEVELOPMENT: Lab research

REFERENCES: Herron, N.R., D.W. Whitehead, and V.J. Miller, 1988, Evolution of an FOCS for Monitoring Dissolved Volatiles. SPIE Proceedings, Boston, MA, p. 37-44. 
COMPOUND CLASS DETECTED: Chlorinated, volatile

ANALYTES: Trichloroethylene

DETECTION LIMIT RANGE: ppm

MANUFACTURER/DEVELOPER: Fiberchem, InC. 3904 Juan Talo NE

Albuquerque, NM 87111 USA

DETECTION METHOD: Refractive index matching on coated fiber optic tip

SUPPORT EQUIPMENT: Laser, spectrometer, detector

CAPABILITIES: VAPOR: $Y$ LIQUID: $Y$ REVERSIBLE: $Y$

STATE OF DEVELOPMENT: Lab research

REFERENCES: Oxenford, J.L., S.M. Klainer, T.M. Salinas, I. Todechiney, J.A. Kennedy, D.K. Dange, and K. Goswami, 1989, Development of a Fiber Optic Chemical sensor for the Monitoring of Trichloroethylene in Drinking water. SPIE Proceedings, Boston, MA, p. 108-114. 
COMPOUND CLASS DETECTED: Chlorinated, volatile

$\begin{aligned} & \text { ANALYTES: } \text { Chloroform } \\ & \text { Trichloroethylene }\end{aligned}$

DETECTION LIMIT RANGE: ppb

MANUFACTURER/DEVELOPER: Lawrence Livermore National Laboratory

P.O. Box $808, \mathrm{~L}-524$

Livermore, CA 94550 USA

DETECTION METHOD: Chemical reaction, fluorescence

SUPPORT EQUIPMENT: Laser, spectrometer, detector, fiber optics

CAPABILITIES: VAPOR: $\mathrm{Y}$ LIQUID: $\mathbf{N}$ REVERSIBLE : $N$

STATE OF DEVELOPMENT: Lab research

REFERENCES: Milanovich, F.P., D.G. Garvis, S.M. Angel, S.M. Klainer, and L. Eccles, 1986, Remote Detection of Organochlorides with a Fiber Optic Sensor. Anal. Instr., 15:137-147.

Angel, S.M., and M.N. Ridley, 1989, Dual-Wavelength Absorption Optrode for Trace Level Measurements of Trichloroethylene and Chloroform. SPIE Proceedings, Boston, MA, p. 115-122. 
COMPOUND CLASS DETECTED: Gaseous hydrocarbon

ANALYTES: Methane

DETECTION LIMIT RANGE: \& level

MANUFACTURER/DEVELOPER: ABB ATOM AB

$A B B$ Corporate Research

Great Britain

DETECTION METHOD: Absorption of light at $1.67 \mathrm{um}$

SUPPORT EQUIPMENT: Laser, detector

CAPABIIITIES: VAPOR: $\mathrm{Y}$ LIQUID: $\mathrm{N}$ REVERSIBLE : $\mathrm{Y}$

STATE OF DEVELOPMENT: Field tested

REFERENCES: Pettersson, H., D.J. Burns, C. Ovren, and T. Hidman, 1988, A Fibre-Optic Gas Detection System For Methane. SPIE Proceedings, London, England, p. 192-199. 
COMPOUND CLASS DETECTED: Gaseous hydrocarbon

ANALYTES: Methane

MANUFACTURER/DEVELOPER: University of Manchester Schuster Laboratory Manchester M13 9PI Great Britain

DETECTION METHOD: Absorption spectroscopy at $1325 \mathrm{~nm}$

SUPPORT EQUIPMENT: Diode laser, spectrometer, detector

CAPABILITIES: $\quad$ VAPOR: $Y$ LIQUID: $N \quad$ REVERSIBLE: $Y$

STATE OF DEVELOPMENT: Lab research

REFERENCES: Mohebati, A., and T.A. King, 1989, Fiber-Optic Remote Gas Sensor With Diode Laser FM Spectroscopy. SPIE Proceedings, Boston, MA, p. 186-193. 
COMPOUND CLASS DETECTED: Gaseous hydrocarbon

ANALYTES: Methane

DETECTION LIMIT RANGE: \& level

MANUFACTURER/DEVELOPER: Tokyo Gas Company Ltd.

16-25 Shibaura, 1-Chome, Minato-ku

Tokyo 105 Japan

DETECTION METHOD: Optical absorption of $3.392 \mathrm{um}$ line

of $\mathrm{He}-\mathrm{Ne}$ laser

SUPPORT EQUIPMENT: Optical fibers, He-Ne laser, photodetector

CAPABIIITIES: $\quad$ VAPOR: $Y$ LIQUID: $N$ REVERSIBLE: $Y$

STATE OF DEVELOPMENT: Lab research

REFERENCES: Tai,H., H. Tanaka, and T. Yoshino, 1987, FiberOptic Evanescent-wave Methane Gas Sensor Using Optical Absorption for the 3.392 um Line of a $\mathrm{He}-\mathrm{Ne}$ Laser. Optics Letters, $12(6): 437-439$. 
COMPOUND CLASS DETECTED: Gaseous hydrocarbon

ANALYTES: Methane

MANUFACTURER/DEVELOPER: University of Maryland

Greenbelt, MD USA

DETECTION METHOD: Infrared absorption

SUPPORT EQUIPMENT: InGaAsP and InGaAs LEDs, infrared spectrometer, detector, fiber optics

CAFABILITIES: VAPOR: $Y$ LIQUID: N REVERSIBLE: $Y$

STATE OF DEVELOPMENT: Lab research

REFERENCES: Chan, K., H. Ito, and H. Inaba, 1987, All Optical Fiber Based Remote Sensing System for Near Infrared Absorption of Low-Level CH4 Gas. J. of Lightwave Tech. LT-5(12): 1706-1711. 
COMPOUND CLASS DETECTED: Nitroaromatic

ANALYTES: $2,4,6$ Trinitrotoluene

DETECTION LIMIT RANGE: ppm

MANUFACTURER/DEVEIOPER: University of New Hampshire

Dept. of Chemistry

Durham, NH 03824 USA

DETECTION METHOD: Chemical reaction, absorbance

SUPPORT EQUIPMENT: LAmp, spectrometer, detector,

fiber optics

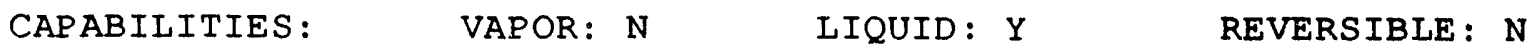

STATE OF DEVELOPMENT: Lab research

REFERENCES: Zhang, Y., D.C. Sundberg, and W.R. Seitz, 1989, Effect of Amine Content on Stability and Response of TNT Sensitive Membranes. SPIE Proceedings, Boston, MA, p. 140-144.

Zhang, Y., and W.R. Seitz, 1989, Single Fiber Absorption Measurements for Remote Detection of 2, 4,6-Trinitrotoluene. Anal. Chim. Acta, 221: 1-9. 
COMPOUND CLASS DETECTED: Nitroaromatic

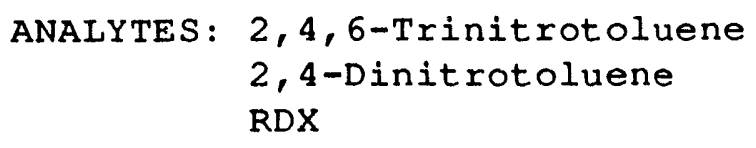

DETECTION METHOD: Chemical reaction, fluorescence

SUPPORT EQUIPMENT: Lamp, spectrophotometer, detector, fiber optics

CAPABILITIES: $\quad$ VAPOR: $N$ LIQUID: $Y$ REVERSIBLE: $Y$

STATE OF DEVELOPMENT: Lab research

REFERENCES: Jian, C., and W.R. Seitz, 1990, Membrane for In Situ Optical Detection of Organic Nitro Compounds Based On Fluorescence Quenching. Anal. Chim. Acta, 237 : 265-271. 
COMPOUND CLASS DETECTED: Phenolic

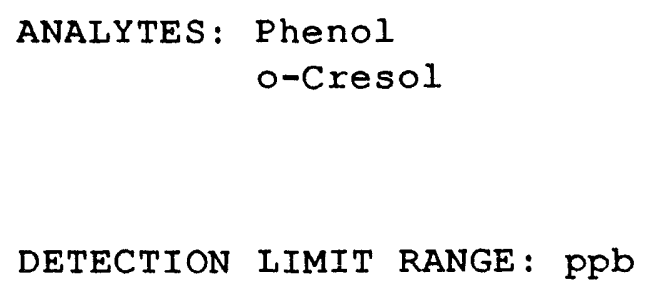

DETECTION METHOD: Laser-induced fluorescence

SUPPORT EQUIPMENT: Laser, spectrometer, detector, fiber optics

CAPABILITIES :

VAPOR: $N$ LIQUID : $Y$

REVERSIBLE : Y

STATE OF DEVELOPMENT: Lab research

REFERENCES: Chudyk, W.A., M.M. Carrabba, and J.E. Kenny, 1985, Remote Detection of Groundwater Contaminants Using Far-Ultraviolet Laser-Induced Fluorescence. Anal. Chem., $57: 1$ 237-1242. 
COMPOUND CLASS DETECTED: Phenolic and nitroaromatic

ANALYTES: Phenol

DETECTION LIMIT RANGE: ppm

MANUFACTURER/DEVELOPER: Western Research Institute

P.O. Box 3395, University Station

Laramie, WY 82071-3395 USA

DETECTION METHOD: Laser Raman spectroscopy with fiber

optic probe

SUPPORT EQUIPMENT: Laser, spectrometer, detector, fiber optics

CAPABILITIES: VAPOR: N IIQUID: $\mathrm{Y}$ REVERSIBLE: $\mathrm{Y}$

STATE OF DEVELOPMENT: Lab research

REFERENCES: Bowen, J.M., P.J. Sullivan, M.S. Blanche, M.E. Essington, and L.J. Noe, 1989, Optical Fiber Raman Spectroscopy Used For Remote In Situ Environmental Analysis. U.S. Pat. 4,802,761. 
COMPOUND CLASS DETECTED: POlyCyclic aromatic hydrocarbon

ANALYTES: Benzo[a]pyrene

DETECTION LIMIT RANGE: ppm

MANUFACTURER/DEVELOPER: University of Dortmund

Dept. of Chemistry,

P.O. Box 500500

Dortmund 50 Germany

DETECTION METHOD: Fluorescence wavelength and lifetime

SUPPORT EQUIPMENT: Laser, spectrometer, detector, fiber optics

CAPABILITIES: VAPOR: N LIQUID: $Y$ REVERSIBLE: $Y$

STATE OF DEVELOPMENT: Lab research

REFERENCES: Niessner, R., W. Robers, and A. Krupp, 1989, Fiber Optical sensor system Using a Tunable Laser for Detection of PAHs on Particles and in Water. SPIE Proceedings, Boston, MA, p. 145-156. 
COMPOUND CLASS DETECTED: POlyCyClic aromatic hydrocarbon

ANALYTES: Benzo[a]pyrene

MANUFACTURER/DEVELOPER: Oak Ridge National Laboratory

P.O. Box 1008, MS -6101

Oak Ridge, TN 37831-6101 USA

DETECTION METHOD: Antibody-antigen reactions, fluorescence

SUPPORT EQUIPMENT: Fluoroimmuno sensor, laser

CAPABILITIES: VAPOR: N LIQUID: Y REVERSIBLE : ?

STATE OF DEVELOPMENT: Lab research

REFERENCES: Frank, C.W., T.D. Anderson, C.R. Cooley, K.E. Hain, S.C.T. Lien, R.L. Snipes, and M.D. Erickson, 1990, Overview of DOE's Field Screening Technology Development Activities. U.S. DOE, Washington, DC. 
COMPOUND CLASS DETECTED: POlyCYClic aromatic hydrocarbon

ANALYTES: Anthracene
Phenanthrene

DETECTION LIMIT RANGE: ppb

MANUFACTURER/DEVELOPER: Indiana University

Dept. of Chemistry

Bloomington, IN 47405 USA

DETECTION METHOD: Molecular-geometric-selective adsorption of PAHs on liquid crystal

SUPPORT EQUIPMENT: Laser, equilateral prism, temperature controller

CAPABILITIES:

VAPOR: Y

LIQUID : $\mathbf{N}$

REVERSIBLE : Y

STATE OF DEVELOPMENT: Lab research

REFERENCES: Zhu, C., and G.M. Hieftje, 1990, Feasibility of Using Liquid Crystals for the Development of Molecularly Selective Fiber-Optic Chemical Sensors. Anal. Chem., 62: 2079-2084. 
COMPOUND CLASS DETECTED: PyridiniC

$\begin{aligned} & \text { ANALYTES: } \text { Pyridine } \\ & \text { Quinoline }\end{aligned}$

DETECTION LIMIT RANGE: ppm

MANUFACTURER/DEVELOPER: EIC Laboratories

111 Downey St.

Norwood, MA 02062 USA

DETECTION METHOD: Surface-Enhanced Raman Spectroscopy

(SERS)

SUPPORT EQUIPMENT: Argon ion laser, spectrometer, photomultiplier tuke

CAPABILITIES: VAPOR: N LIQUID: $Y$ REVERSIBLE: $Y$

STATE OF DEVELOPMENT: Lab research

REFERENCES: Carrabba, M.M., R.B. Edmonds, and R.D Rauh, 1987, Feasibility Studies for the Detection of Organic Surface and Subsurface water Contaminants by Surface-Enhanced Raman Spectroscopy on Silver Electrodes. Anal. Chem., 59: 2559-2563. 
COMPOUND CLASS DETECTED: PyridiniC

ANALYTES: Pyridine

DETECTION LIMIT RANGE: \& level

MANUFACTURER/DEVELOPER: EIC Laboratories

111 Downey St.

Norwoodd, MA 02062 USA

DETECTION METHOD: Surface-enhanced Raman spectroscopy on silver probe held at constant potential

SUPPORT EQUIPMENT: Laser, monochromator, detector, potentiostat, computer, fiber optics

CAPABILITIES: $\quad$ VAPOR: $N \quad$ LIQUID: $Y$ REVERSIBLE: $Y$

STATE OF DEVELOPMENT: Lab research

REFERENCES: Carrabba, M.M., R.B. Edmonds, P.J. Marren, and R.D. Rauh, 1989, The Suitability of Surface Enhanced Raman Spectroscopy (SERS) to Fiber Optic Chemical Sensing of Aromatic Hydrocarbon Contamination in Groundwater. First Annual Field Screeing Methods for Hazardous Waste Site Investigations Proceedings, Las Vegas, NV, EPA/600/D-89/189. 
COMPOUND CLASS DETECTED: Pyridinic and aliphatic alcohol

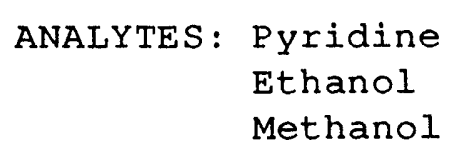

DETECTION METHOD: Surface-enhanced Raman spectroscopy

SUPPORT EQUIPMENT: Spectrometer, laser, potentiostat interfaced to computer

CAPABILITIES: VAPOR: $Y$ LIQUID: $Y$ REVERSIBLE: $Y$ STATE OF DEVELOPMENT: Lab research

REFERENCES: Carrabba, M.M., and R.D. Rauh, 1988, Remote Fiber Optic Sensor for Gaseous and Liquid Environments based on Surface Enhanced Raman Spectroscopy--Phase I. EIC Laboratories, Final Report for Period September 1987-February 1988. DON Contract N00014$87-\mathrm{C}-0859$. 
COMPOUND CLASS DETECTED: Various

ANALYTES: Organic compounds

DETECTION LIMIT RANGE: not clear

MANUFACTURER/DEVELOPER: EIC Laboratories

111 Downey St.

Norwood, MA 02062 USA

DETECTION METHOD: Surface-enhanced Raman spectroscopy

SUPPORT EQUIPMENT: Spectrometer, diode laser, CCD detector

CAPABILITIES: $\quad$ VAPOR: $N \quad$ LIQUID: $Y \quad$ REVERSIBLE: Y

STATE OF DEVELOPMENT: Field tested

REEERENCES: Frank, C.W., T.D. Anderson, C.R. Cooley, K.E. Hain, S.C.T. Lien, R.L. Snipes, and M.D. Erickson, 1990, Overview of DOE's Field Screening Technology Development Activities. U.S. DOE, Washington, DC.

Argonne National Laboratory, 1990, Applied Research and Development Private Sector Activities. Interim Report on FY 90 Contracting, U.S. DOE, Germantown, $\mathrm{MD}$. 
COMPOUND CLASS DETECTED: Various

ANALYTES: Acetone

DETECTION LIMIT RANGE: \& level

MANUFACTURER/DEVELOPER: University of Washington

Dept. of Chemistry

Seattle, WA 98195 USA

DETECTION METHOD: Chemical fuse alters light transmission

SUPPORT EQUIPMENT: Lamp, detector

CAPABILITIES: $\quad$ VAPOR: $N$ LIQUID: $Y$ REVERSIBLE: N

STATE OF DEVELOPMENT: Lab research

REFERENCES: Tenge, B., A.Q. Grunke, and D.E. Honigs, 1987, Fiber Optic Chemfuse Sensors. InTech, October: 29-33. 
COMPOUND CLASS DETECTED: Various

ANALYTES: Polycyclic aromatic hydrocarbons Chlorophyll

DETECTION LIMIT RANGE: ppb

MANUFACTURER/DEVELOPER: Turner Designs

$920 \mathrm{~W}$. Maude Ave.

Sunnyvale, CA 94086 USA

DETECTION METHOD: Fluorescence after excitation by filtered UV light

SUPPORT EQUIPMENT: Lamp, fluorometer

CAPABILITIES: VAPOR: $N$ LIQUID: $Y$ REVERSIBLE: $Y$

STATE OF DEVELOPMENT: Commercial

REFERENCES: Turner Designs, 1990 , Field Fluorometry. Manufacturer's Literature. 
COMPOUND CLASS DETECTED: Various

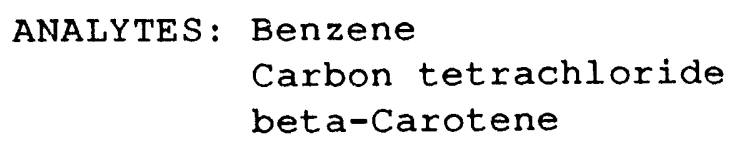

REFERENCES: Schwab, S.D., and R.L. MCCreery, 1987, Remote, Long-Pathlength Cell for High-Sensitivity Raman Spectroscopy. Appl. Spec., 41(1): 126-130. 
COMPOUND CLASS DETECTED: Various

ANALYTES: Organic compounds

MANUFACTURER/DEVELOPER: Oak Ridge National Laboratory

P.O. Box 2008

Oak Ridge, TN 37831 USA

DETECTION METHOD: Surface-enhanced Raman spectroscopy (SERS)

SUPPORT EQUIPMENT: Laser, spectrometer, detector, fiber optics

CAPABILITIES:

VAPOR: $\mathrm{N}$

LIQUID: Y

REVERSIBLE : ?

STATE OF DEVELOPMENT: Lab research

REFERENCES: Frank, C.W., T.D. Anderson, C.R. Cooley, K.E. Hain, S.C.T. Lien, R.L. Snipes, and M.D. Erickson, 1990, Overview of DOE's Field Screening Technology Development Activities. U.S. DOE, Vashington, DC. 
COMPOUND CLASS DETECTED: Various aromatic

ANALYTES: p-Aminobenzoic acid

Fluorescein isothiocyanate

Terephthalic acid

DETECTION LIMIT RANGE: ppb

MANUFACTURER/DEVELOPER: Oak Ridge National Laboratory

Health and Safety Research Division

Oak Ridge, TN 37831-6101 USA

DETECTION METHOD: Surface-enhanced Raman spectroscopy (SERS)

SUPPORT EQUIPMENT: Spectrometer, laser, detector, computer

CAPABILITIES: VAPOR: $N$ LIQUID: $Y$ REVERSIBLE: $N$

STATE OF DEVELOPMENT: Lab research

REFERENCES: Bello, J.M., V.A. Narayanan, D.L. Stokes, and T. Vo-Dinh, 1990, Fiber-optic Remote Sensor for In Situ Surfac $z-E n h a n c e d$ Raman Scattering Analysis. Anal. Chem., 62: 2437-2441. 
COMPOUND CLASS DETECTED: Various aromatic

$\begin{aligned} \text { ANALYTES: } & \text { Dopamine } \\ & \text { Catechol } \\ & \text { Promethazine }\end{aligned}$

DETECTION LIMIT RANGE: ppb

MANUFACTURER/DEVELOPER: New Mexico State University

Dept. of Chemistry

Las Cruces, NM 88003 USA

DETECTION METHOD: Amperometric electrodes coated with different permselective films

SUPPORT EQUIPMENT: Four-electrode thin-layer flow cell, voltammetric analyzer, recorder

CAPABILITIES: VAPOR: N N LIQUID: $Y$ REVERSIBLE: $Y$

STATE OF DEVELOPMENT: Lab research

REFERENCES: Wang, J., G.D. Rayson, Z. Lu, and H. Wu, 1990, Coated Amperometric Electrode Arrays for Multicomponent Analysis. Anal. Chem., 62: 19241927. 
COMPOUND CLASS DETECTED: Various hydrocarbon

ANALYTES: Hydrocarbons

DETECTION LIMIT RANGE: PPM

MANUFACTURER/DEVELOPER: Forestry Suppliers, Inc.

205 W. Rankin St. P.O. Box 8397

Jackson, MS 39284-8397 USA

DETECTION METHOD: Platinum catalyst, electrical resistance change

SUPPORT EQUIRMENT: Batteries, resistance meter

CAPABILITIES: VAPOR: $Y$ LIQUID: $N$ REVERSIBLE: $Y$

STATE OF DEVELOPMENT: Commercial

P.EFERENCES: Forestry Suppliers, Inc., 1991, Leaking Underground Storage Tank (LUST) Meter. Environmental Source Circlar, Vol 2, No. 1 . 
COMPOUND CLASS DETECTED: Various hydrocarbon

ANALYTES: Hydrocarbons

MANUFACTURER/DEVELOPER: Arizona Instrument Corporation

1100 East University Drive, P.O. Box 1930

Tempe, AZ 85280 USA

DETECTION METHOD: Reflectance, infrared detection

SUPPORT EQUIPMENT: Computer, optical sensing probe

CAPABILITIES: VAPOR: Y LIQUID: N NEVERSIBLE: $Y$

STATE OF DEVELOPMENT: Commercial

REFERENCES: Arizona Instrument Corp., 1991, Soil Sentry Underground Monitoring System. Product Information Circular. 
COMPOUND CLASS DETECTED: Various hydrocarbon

ANALYTES: Hydrocarbons

DETECTION LIMIT RANGE: \& level

MANUEACTURER/DEVELOPER: EBW

Muskegon, MI 49441 USA

DETECTION METHOD: Solid-state sensor

SUPPORT EQUIPMENT: Ancillary electronics

CAPABILITIES: VAPOR: $Y$ LIQUID: $N$ REVERSIBLE: $Y$

STATE OF DEVELOPMENT: Commercial

REFERENCES: EBW Product Bulletin, 1990, Product Literature. 
COMPOUND CLASS DETECTED: Various hydrocarbon

ANALYTES: HYdrocarbons

DETECTION LIMIT RANGE: pPm

MANUFACTURER/DEVELOPER: Warrick Controls, Inc.

4237 Normandy Court

Royal Oak, MI 48073 USA

DETECTION METHOD: Coated solid-state device, change in resistance due to adsorption (adsistor), can be re-zeroed

SUPPORT EQUIPMENT · AnCillary electronics

CAPABILITIES: VAPOR: $Y$ LIQUID: $Y$ REVERSIBLE: $N$

STATE OF DEVELOPMENT: Commercial

REFERENCES: Warrick Controls, 1991, Product Bulletin. 
COMPOUND CLASS DETECTED: Various hydrocarbon

ANALYTES: Hydrocarbons

MANUFACTURER/DEVELOPER: Emhart Electrical Group

3029 E. Washington St. P.O. Box 706

Indianapolis, IN 46206-0706 USA

DETECTION METHOD: Resistive change due to heat of vapor adsorption

SUPPORT EQUIPMENT: Resistance meter and controllers

CAPABILITIES :

VAPOR: $Y$

LIQUID : Y

REVERSIBLE : Y

STATE OF DEVELOPMENT: Commercial

REFERENCES: Pollulert Systems, Manufacturer's Literature. 
COMEOUND CLASS DETECTED: Various hydrocarbons

ANALYTES: Hydrocarbons

MANUFACTURER/DEVELOPER: Leak-X Corporation

1626 Bronxdale Avenue

Bronx, NY 10462 USA

DETECTION METHOD: Relay closure activates remote alarm when sensor detects hydrocarbons

SUPPORT EQUIPMENT: Controller, cables

CAPABILITIES: VAPOR: $Y$ LIQUID: $Y$ REVERSIBLE: $N$

STATE OF DEVELOPMENT: Commercial

REFERENCES: Leak-X Corporation, 1991, LEAKX Better Bottom Line Monitoring Systems for All Owners of Underground Tanks, Manufacturer's Literature. 
COMPOUND CLASS DETECTED: Various hydrocarbon

ANALYTES: Oil

DETECTION LIMIT RANGE: ppm

MAINUF ACTURER/DEVELOPER: U.S. EPA

Environmental Monitoring and Support Lab Cincinnati, $\mathrm{OH} 45268 \mathrm{USA}$

DETECTION METHOD: Refractive index change of a selective coating on a fiber optic cable

SUPPORT EQUIPMENT: Laser, Detector

CAPABILITIES: VAPOR: $N$ LIQUID: $Y$ REVERSIBLE: $Y$

STATE OF DEVELOPMENT: Lab research

REFERENCES: Kawahara, F.K., and R.A. Fiutem, 1983, Development of a Novel Method for Monitoring Oils in Waters. Anal. Chim. Acta, 151: 315-327. 
COMPOUND CLASS DETECTED: Various volatile

ANALYTES: Volatile organics

DETECTION LIMIT RANGE: ppm

MANUFACTURER/DEVELOPER: Universal Sensors and Devices

9205 Alabama Avenue, Unit C

Chatsworth, CA 91311 USA

DETECTION METHOD: Diffusion onto metal oxide semiconductor

SUPPORT EQUIPMENT: SuPport electronics

STATE OF DEVELOPMENT: Commercial

REFERENCES: Universal Sensors and Devices, Inc., 1990, Condensed Product Catalog. Product Bulletin VS9002 . 
COMPOUND CLASS DETECTED: Various volatile

ANALYTES: Volatile organics

DETECTION LIMIT RANGE: $\%$ level

MANUFACTURER/DEVELOPER: Sandia National Laboratories

P.O. Box 5800

Albuquerque, NM 87185 USA

DETECTION METHOD: Decrease in reflectivity of polymerized fluorocarbon film

SUPPORT EQUIPMENT: LamP, detector, fiber optics

CAPABILITIES: VAPOR: $Y$ LIQUID: $N$ REVERSIBLE: $Y$

STATE OF DEVELOPMENT: Lab research

REFERENCES: Butler, M.A., A.J. RicCo, and R. Buss, 1990, Fiber Optic Micromirror Sensor for Volatile organic Compounds. J. Electrochemical Soc., $137(4)$ : 13251326. 
APPIHDIX $B$

Metals Sensors 
COMPOUND CLASS DETECTED: Metal

ANALYTES: Aluminum(III)

Beryllium(II)

DETECTION LIMIT RANGE: ppm

MANUFACTURER/DEVELOPER: University of New Hampshire

Dept. of Chemistry

Durham, NH 03824 USA

DETECTION METHOD: Chemical reaction with morin, fluorescence

SUPPORT EQUIPMENT: Spectrofluorometer, pH meter, fiber optics

CAPABILITIES: VAPOR: N LIQUID: $Y$ REVERSIBLE: $Y$

STATE OF DEVELOPMENT: Lab research

REFERENCES: Saari, L., and W.R. Seitz, 1983, Immobilized Morin as Fluorescence Sensor for Determination of Aluminum(III). Anal. Chem., 55: 667-670.

Saari, L., and W.R. Seitz, 1984, Optical Sensor for Beryllium Based on Immobilized Morin Fluorescence. Analyst, 109: 655-657. 
COMPOUND CLASS DETECTED: Metal

$\begin{aligned} \text { ANALYTES: } & \text { Aluminum(II) } \\ & \text { Magnesium(II) } \\ & \text { zinc (II) }\end{aligned}$

DETECTION LIMIT RANGE: ppb

MANUFACTURER/DEVELOPER: University of New Hampshire

Dept. of Chemistry

Durham, NH 03824 USA

DETECTION METHOD: Chemical reaction with quinolin-8-ol sulfonate, fluorescence

SUPPORT EQUIPMENT: Tungsten-halogen lamp, spectrometer, photomultiplier detector

CAPABILITIES :

VAPOR: $\mathrm{N}$

LIQUID : Y

REVERSIBLE : Y

STATE OF DEVELOPMENT: Lab research

REFERENCES: Seitz, W.R., and Z. Zhujun, 1985, A Fluorescent Sensor for Aluminum(III), Magnesium(II), Zinc(II), and Cadmium(II) Based on Electrostatically Immobilized Quinolin-8-ol Sulfonate. Anal. Chim. Acta, 171: 251-258. 
COMPOUND CLASS DETECTED: Metal

$\begin{aligned} \text { ANALYTES: } & \text { Aluminum(III) } \\ & \text { Gallium(III) } \\ & \text { Indium(III) }\end{aligned}$

DETECTION LIMIT RANGE: $\mathrm{pPb}$

MANUFACTURER/DEVELOPER: Indiana University

Dept. of Chemistry

Bloomington, IN 47405 USA

DETECTION METHOD: Lifetime-resolved fluorimetry of complexes with fluorescent indicator

SUPPORT EQUIPMENT: MOde-locked laser, fluorometer, detector, oscilloscope, fiber optics

CAPABILITIES: $\quad$ VAPOR: $N$ LIQUID: $Y$ REVERSIBLE: N

STATE OF DEVELOPMENT: Lab research

REFERENCES: Carrol1, M.K., F.V. Bright and G.M. Hieftje, 1989, Fiber-optic Time-Resolved Fluorescence sensor for the Simultaneous Determination of AI(III), and Ga(III), or In(III). Anal. Chem. 1989, 61, Vol 15 . 
COMPOUND CLASS DETECTED: Metal

ANALYTES: Actinides and lanthanides

MANUFACTURER/DEVELOPER: University of New Mexico

Albuquerque, NM USA

DETECTION METHOD: Piezoelectric quartz crystal microbalance with immobilized chelating agent

CAPABILITIES: VAPOR: N LIQUID: Y REVERSIBLE: ?

STATE OF DEVELOPMENT: Lab research

REFERENCES: Carey, P., V. Hamilton, P. Mendoza, L. Wangen, W. Smith, B. Jorgensen, G. Jarvinen, and P. Smith, 1989, Chemical Sensors. LA-11715-MS UC-701. 
COMPOUND CLASS DETECTED: Metal

ANALYTES: Calcium(II)

DETECTION LIMIT RANGE: ppm

MANUFACTURER/DEVELOPER: Ames Laboratory,

Iowa State University

Dept. of Chemistry

Ames, IA 50011 USA

DETECTION METHOD: Chemical reaction, diffuse reflectance spectroscopy

SUPPORT EQUIPMENT: Lamp, spectrometer, detector, fiber optics

CAPABILITIES:

VAPOR: $N$

LIQUID : Y

REVERSIBLE : N

STATE OF DEVELOPMENT: Lab research

REFERENCES: Chau, L.K., and M.D. Porter, 1990, Optical Sensor for Calcium: Performance, Structure, and Reactivity of Calcichrome Immobilized at an Anionic Polymer Film. Anal. Chem,, 62: 1964-1971. 
COMPOUND CLASS DETECTED: Metal

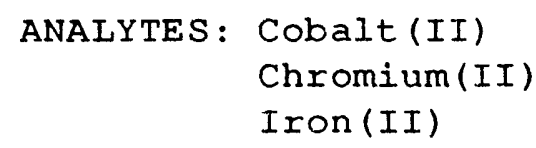

DETECTION LIMIT RANGE : ppb

MANUFACTURER/DEVELOPER: Indiana University Dept. of Chemistry

Bloomington, IN 47405 USA

DETECTION METHOD: Fluorescence quenching of indicator dye

SUPPORT EQUIPMENT: Lamp, fluorometer, detector, fiber optics

CAPABILITIES: $\quad$ VAPOR: N NIQUID: $Y$ REVERSIBLE: Y

STATE OF DEVELOPMENT: Lab research

REFERENCES: Bright, F.V., G.E. Poirier, and G.M. Hieftje, 1987, A New Ion Sensor Based on Fibel Optics. Talanta, $35(2): 113-118$. 
COMPOUND CLASS DETECTED: Metal

ANALYTES: Copper(II)

DETECTION LIMIT RANGE: \& level

MANUFACTURER/DEVELOPER: Indiana University

Dept. of Chemistry

Bloomington, IN 47405 USA

DETECTION METHOD: Optical absorbance by $\mathrm{Cu}(\mathrm{II})$ in the near infrared region

SUPPORT EQUIPMENT: Absorption cell, Vespel housing, lamp, spectrometer, photomultiplier tube, digital multimeter

CAPABILITIES: VAPOR: N LIQUID: $\mathrm{Y}$ REVERSIBLE: $\mathrm{Y}$

STATE OF DEVELOPMENT: Lab research

REFERENCES: Freeman, J.E., A.G. Childers, A.W. Steele, and G.M. Hieftje, 1985, A Fiber-Optic Absorption Cell for Remote Determination of Copper in Industrial Electroplating Baths. Anal. Chim. Acta, 177: 121128. 


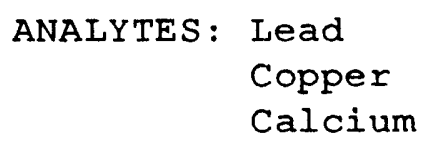

CAPABILITIES :

VAPOR: $\mathrm{N}$

STATE OF DEVELOPMENT: Lab research

REFERENCES: Carron, K., K. Mullen, M. Lanouette, and H. Angersbach, 1991, Selective-Ultratrace Detection of Metal Ions with SERS. Appl. Spec., $45(3): 420-423$. 
ANALYTES: Magnesium(II)

DETECTION LIMIT RANGE: pPm

MANUFACTURER/DEVELOPER: University of New Hampshire Dept. of Chemistry

Durham, NH 03824 USA

DETECTION METHOD: Chemical reaction, fluorescence spectrophotometry

SUPPORT EQUIPMENT: Photometer, spectrofluorometer, fiber optics

CAPABILITIES: $\quad$ VAPOR: $N$ LIQUID: $Y$ REVERSIBLE: N

STATE OF DEVELOPMENT: Lab research

REFERENCES: Wangbai, M., z. Zhujun, and W.R. Seitz, 1989, Poly(vinyl alcohol)-Based Indicators for Optical pH and Mg(II) Sensing. ACS Symposium series No. 403, Chemical Sensors and Microinstrumentation. 
COMPOUND CLASS DETECTED: Metal.

ANALYTES: Magnesium

Cadmium

DETECTION IIMIT R.ANGE: ppb

MANUFACTURER/DEVELOPER: Naval Oceans Systems Center

Marine Environmental Branch

San Diego, CA 92152-5000 USA

DETECTION METHOD: Chemical reaction with 8HQS, fluorescence

SUPPORT EQUIPMENT: Optical multichannel analyzer, spectrometer, lamp, fiber optics

CAPABILITIES: $\quad$ VAPOR: $N \quad$ LIQUID: $Y \quad$ REVERSIBLE: $Y$

STATE OF DEVELOPMENT: Lab research

REFERENCES: Inman, S.M., E.J. Stromvall, and S.H. Lieberman, 1989, Pressurized Membrane Indicator System for Fluorogenic-Based Fiber-optic Chemical Sensors. Anal. Chim. Acta, 217: 249-262. 
COMPOUND CLASS DETECTED: Metal

ANATYTES: POtassium

DETECTION LIMIT RANGE: ppb

MANUEACTURER/DEVELOPER: Keio University

3-14-1 Hiyoshi

Kohcku-ku, Yokohama 223 Japan

DETECTION METHOD: Chemical reaction with LAD dye, absorbance

SUPPORT EQUIPMENT: LAMP, spectrometer, detector

CAPABILITIES: VAPOR: $N$ LIQUID: $Y$ REVERSIBLE: $N$

STATE OF DEVELOPMENT: Lab research

REFERENCES: Suzuki, K., H. Ohzora, K. Miyazaki, K. Watanabe, H. Inoue, and T. Shirai, 1990, Fibre-optic Potassium Ion Sensors Based on a Neutral Ionophore and a Novel Lipophilic Anionic Dye. Anal. Chim. Acta, 237: $155-164$. 
COMPOUND CLASS DETECTED: Metal

ANALYTES: Potassium

DETECTION LIMIT RANGE: ppm

MANUFACTURER/DEVELOPER: Karl Franzens University Inst. of Organic Chemistry A-8010 Graz Austria

DETECTION METHOD: Chemical reaction with potential-sensitive dye, fluorescence

SUPPORT EQUIPMENT: Lamp, spectrometer, fluorometer

CAPABILITIES: $\quad$ VAPOR: $N \quad$ LIQUID: $Y \quad$ REVERSIBLE: $Y$

STATE OF DEVELOPMENT: Lab research

REFERENCES: Wolfbeis, O.S., and B.P.H. Schaffar, 1987, Optical Sensors: An Ion-Selective Optrode For Potassium. Anal. Chim. Acta, 198: 1-12. 
COMPOUND CLASS DETECTED: Metal

ANALYTES: Rare earths and actinides

MANUFACTURER/DEVELOPER: Lawrence Berkeley Laboratory

M.S. 90-2024

Berkeley, CA 94720 USA

DETECTION METHOD: Photothermal spectroscopy

SUPPORT EQUIPMENT: Photoacoustic sensor, laser, fiber optics

CAPABILITIES: $\quad$ VAPOR: N LIQUID: $\mathrm{N}$ REVERSIBLE : ?

STATE OF DEVELOPMENT: Lab research

REFERENCES: Frank, C.W., T.D. Anderson, C.R. Cooley, K.E. Hain, S.C.T. Lien, R.L. Snipes, and M.D. Erickson, 1990, Overview of DOE's Field Screening Technology Development Activities. U.S. DOE, Washington, DC. 
COMPOUND CLASS DETECTED: Metal

$\begin{aligned} \text { ANALYTES: } & \text { Zinc } \\ & \text { Cadmium }\end{aligned}$

DETECTION LIMIT RANGE: ppb

MANUFACTURER/DEVELOPER: Naval Ocean Systems Center

Marine Env. Branch, Code 522

San Diego, CA 92152 USA

DETECTION METHOD: Chemical reaction with PTAQ, fluorescence

SUPPORT EQUIPMENT: Laser, spectrometer, optical analyzer, fiber optics

CAPABILITIES: VAPOR: N LIQUID: $\mathrm{Y}$ REVERSIBLE: ?

STATE OF DEVELOPMENT: Lab research

REFERENCES: Lieberman, S.H., S.M. Inman, and G.A. Theriault, 1989, Use of Time-Resolved Spectral Fluorometry for Improving Specificity of Fiber Optic-Based Chemical Sensors. SPIE Proceedings, Boston, MA, p. 94. 
COMPOUND CLASS DETECTED: Metal

\author{
ANALYTES: Zinc \\ Magnesium
}

DETECTION LIMIT RANGE: ppb

MANUFACTURER/DEVELOPER: Naval Ocean Systems Center

San Diego, CA 92152-5000 USA

DETECTION METHOD: Fluorogenic indicator

SUPPORT EQUIPMENT: Lamp, detector

CAPABILITIES: VAPOR: $N$ LIQUID: $Y$ REVERSIBLE: $Y$

STATE OF DEVELOPMENT: Lab research

REFERENCES: Lieberman, S.H., S.M. Inmai, and E.J. Stromvall, 1987, Fiber Optic-Fluorescence Sensors for Remote Detection of Chemical species in seawater. Chemical Sensors, Dennis R. Turner, ed., p. 464475 . 
COMPOUND CLASS DETECTED: Metal

ANALYTES: Various metals

DETECTION LIMIT RANGE: ppb

MANUFACTURER/DEVELOPER: New Mexico State University

Dept. of Chemistry

Las Cruces, NM 88003 USA

DETECTION METHOD: Interfacial accumulation of metal on surface of working electrode

SUPPORT EQUIPMENT: Reference electrode, voltammeter

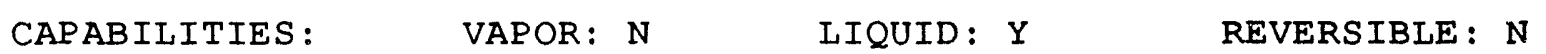

STATE OF DEVELORMENT: Lab research

REFERENCES: Wang, J., 1987, Advances in Adsorptive Stripping voltammetry. Anal. Proc., $24:$ 325-326.

Wang, J., 1983, On-ljine Sensors for Trace Metals. American Lab., pp. 14. 
APPENDIX C

Anion and Cation sensors 

ANALYTES: Bromide Chloride Iodide

MANUFACTURER/DEVELOPER: Karl Franzens University Inst. of Organic Chemistry A-8010 Graz Austria

DETECTION METHOD: Potentiometic measurement of boundary potentials using electrochromic dyes

SUPPORT EQUIPMENT: Lamp, spectrofluorometex

CAPABILITIES: VAPOR: $N$ LIQUID: $Y$ REVERSIBLE: $Y$

STATE OF DEVELOPMENT: Lab research

REFERENCES: Schaffar, B.B.P, and O.S. Wolfbeis, 1988, New Optical Chemical Sensors Based on The LangmuirBlodgett Technique. SPIE Proceedings, Boston, Massachusetts, pp. 122-129. 
COMPOUND CLASS DETECTED: Anion

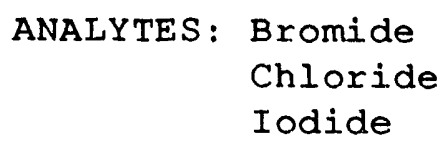

DETECTION LIMIT RANGE: Ppm

MANUFACTURER/DEVELOPER: Karl Franzens University

Institute for Organic Chemistry

A-8010 Graz Austria

DETECTION METHOD: Fluorescence quenching of acridinium and quinolinium indicators

SUPPORT EQUIPMENT: Spectrofluorometer, fiber optics

CAPABILITIES: $\quad$ VAPOR: $N$ LIQUID: $Y$ REVERSIBLE: $Y$

STATE OF DEVELOPMENT: Lab research

REFERENCES: Urbano, E., H. Offenbacher, and O.S. Wolfbeis, 1984, Optical Sensor for Continuous Determination of Halides. Anal. Chem, 56: 427-429. 
COMPOUND CLASS DETECTED: Anion

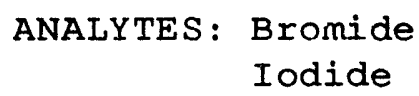

DETECTION METHOD: Fluorescence quenching of quinine and harmane

SUPPORT EQUIPMENT: LAMP, spectrometer, photomultiplier, fiber optics

CAPABILITIES : $\quad$ VAPOR: $N \quad$ LIQUID: $Y \quad$ REVERSIBLE: $Y$

STATE OE DEVELOPMENT: Lab research

REFERENCES: Zhu, C., F.V. Bright, and G.M. Hieftje, 1990, Simultaneous Determination of $B r$ and $I$ with a Multiple Fiber-optic Fluorescence sensor. Appl. Spec., $44(1): 59-63$. 
COMPOUND CLASS DETECTED: Anion

ANALYTES: Carbonate

DETECTION LIMIT RANGE: ppm

MANUFACTURER/DEVELOPER: Fiberchem, InC.

1181 Grier Drive, Suite B

Las Vegas, NV 89119 USA

DETECTION METHOD: Fluorescence of $\mathrm{pH}$ sensitive indicator

SUPPORT EQUIPMENT: Lamp, spectrometer/filter, detector, fiber optics

CAPABILITIES: VAPOR: $N$ LIQUID: $Y$ REVERSIBLE: $Y$

STATE OF DEVELOPMEN $\mathrm{r}$ : Lab research

REFERENCES: Goswami, K., J.A. Kennedy, D.K. Dandge, S.M. Klainer, and J.N. Tokar, 1989 , A Fiber Optic Chemical Sensor for Carbon Dioxide Dissolved in Sea Water. SPIE Proceedings, Boston, MA, p. 123-129. 
COMPOUND CLASS DETECTED: Anion

ANALYTES: Carbonate

LETECTION LIMIT RANGE: PPM

MANUFACTURER/DEVEIOPER: University of New Hampshire

Dept. of Chemistry

Durham, NH 03824 USA

DEIECTION METHOD: Chemical reaction with 8-hydroxy-1,3,6pyrenetrisulfonic acid, fluorescence

SUPPORT EQUIPMENT: Sample cell, lamp, fluorometer

CAPABIIITIES: $\quad$ VAPOR: $N$ LIQUID: $Y$ REVERSIBLE: $Y$

STATE OF DEVELOPMENT: Lab research

REEERENCES: Zhujun, Z., and W.R. Seitz, 1984, A Carbon Dioxide Sensor Based on Fluorescence. Anal. Chim. Acta, $160: 305-309$. 
ANALYTES: Cyanide

DETECTION LIMIT RANGE: ppb

MANUFACTURER/DEVELOPER: University of Kentucky

Dept. of Chemistry

Lexington, KY 40506-0055 USA

DETECTION METHOD: Chemical reaction with metalloporphyrins and corrins, absorption

SUPPORT EQUIPMENT: Lamp, spectrometer, photomultiflier tube

CAPABIIITIES: VAPOR: $N$ IIQUID: $Y$ PEVERSIBLE: $Y$

STATE OF DEVELOPMENT: Lab research

REFERENCES: Freeman, M.K., and L.G. Bachas, 1990, Fiber-Optic Probes for Cyanide Using Metalloporphyrins and a Corrin. Anal. Chim. Acta, 241: 119-125. 
COMPOUND CLASS DETECTED: Anion

ANALYTES: Fluoride

DETECTION LIMIT RANGE: ppm

MANUFACTURER/DEVELOPER: University of Manchester P.O. Box 88

Manchester M601QD Great Britain

DETECTION METHOD: Chemical reaction, fluorescence

SUPPORT EQUIPMENT: Lamp, photomultiplier, current amplifier, recorder

CAPABILITIES :

VAPOR: $N$

LIQUID : Y

REVERSIBLE : Y

STATE OF DEVELOPMENT: Lab research

REFERENCES: Russel1, D.A., and R. Narayanaswamy, 1989, An Optical Fibre Sensor for Fluoride. Anal. Chim. Acta, 220: 75-81. 
COMPOUND CLASS DETECTED: Anion

ANALYTES: Iodide

DEIECTION LIMIT RANGE: pPM

MANUFACTURER/DEVELOPER: Indiana University Dept. of Chemistry

Bloomington, IN 46405 USA

DETECTION METHOD: Fluorescence quenching of adsorbed rhodainine $6 \mathrm{G}$ by iodide ion

SUPPORT EQUIPMENT: Argon-ion laser, monochromator, detector, computer

CAPABILITIES: VAPOR: $N$ LIQUID: $Y$ REVERSIBLE : ?

STATE OF DEVELOPMENT: Lab research

REFERENCES: Wyatt, W.A., F.V. Bright, and G.M. Hieftje, 1987, Characterization and Comparison of Three Fiberoptic Sensors for Iodide Determination Based on Dynamic Fluorescence Quenching of Rhodamine 6G. Anal. Chem., 59: 2272-2276. 
COMPOUND CLASS DETECTED: Anion

ANALYTES: Sulfide

DETECTION LIMIT RANGE: ppm

MANUFACTURER/DEVELOPER: University of Manchester UMIST, P.O. BOX 88

Manchester M60 1QD UK

DETECTION METHOD: Chemical reaction with immobilized

reagents, reflectance measurement

SUPPORT EQUIPMENT: Lamp, optical chopper, spectometer, photomultiplier, fiber optics

CAPABILITIES: $\quad$ VAPOR: $N$ LIQUID: $Y$ REVERSIBLE: $N$

STATE OF DEVELOPMENT: Lab research

REFERENCES: Narayanaswamy, R., and F. Sevilla III, 1986, Flow Cell studies with Immobilized Reagents for the Development of an Optical Fibre Sulphide Sensor. Analyst, 111: 1085-1088. 
COMPOUNND CLASS DETECTED: Anion

ANALYTES: Sulfide

DETECTION LIMIT RANGE: ppm

MANUFACTURER/DEVELOPER: Universidad Complutense 28040 Madrid Spain

DETECTION METHOD: Chemical reaction with $\mathrm{N}, \mathrm{N}-$ dimethyl-pphenylenediamine to form methylene blue, reflectance measured at $690 \mathrm{~nm}$

SUPPORT EQUIPMENT: Lamp, spect $\ddot{r}$ ophotometer, photomultiplier, fiber optics

CAPABILITIES :

VAPOR: $\mathrm{N}$

LIQUID: $Y$

REVERSIBLE : N

STATE OF DEVELOPMENT: Lab research

REFERENCES: Martinez, A., M.C. Moreno, and C. Camara, 1986, Sulfide Determination by N, N-dimethyl-pphenylenediamine Immobilization in Cationic Exchange Resin Using an optical Fiber system. Anal. Chem., 58: 1877-1881. 
COMPOUND CLASS DETECTED: Cation

ANALYTES: Ammonium

DETECTION LIMIT RANGE : Ppm

MANUFACTURER/DEVELOPER: Karl Franzens University Institut fur Organishe Chemie A-8010 Graz Austria

DETECTION METHOD: Eluorescence of $\mathrm{pH}$ indicator, semipermeable membrane

SUPPORT EQUIPMENT: Lamp, fluorometer, fiber optics

CAPABILITIES: $\quad$ VAPOR: $Y \quad$ LIQUID: $Y \quad$ REVERSIBLE: Y

STATE OF DEVELOPMENT: Lab research

REFERENCES: Wolfbeis, O.S., and H.E. Posch, 1986, Fibre-Optic Fluorescing Sensor for Ammonia. Anal. Chim. Acta, 185: $321-327$. 
COMPOUND CLASS DETECTED: Cation

ANALYTES: 'Ammonium

DETECTION LIMIT RANGE: pPm

MANUFACTURER/DEVELOPER: University of Iowa

Dept. of Chemistry

Iowa City, IA 52242 USA

DETECTION METHOD: Entrapment of $\mathrm{pH}$ indicator solution behind gas-permeable membrane

SUPPORT EQUIPMENT: Lamp, illuminator, constant voltage transformer, photomultiplier tube

CAPABILITIES: VAPOR: $N$ LIQUID: $\mathrm{Y}$ REVERSIBLE: ?

STATE OF DEVELOPMENT: Lab research

REFERENCES: Rhines, T.D., and M.A. Arnold, 1988, Simplex Optimization of a Fiber-Optic Ammonia Sensor Based on Multiple Indicators. Anal. Chem., 60: 76-81.

Arnold, M.A., and T.J. Ostler, 1986, Fiber Optic Ammonia Gas Sensing Probe. Anal. Chem., 58:11371140 . 
COMPOUND CLASS DETECTED: Cation

ANALYTES: Ammonium

DETECTION LIMIT RANGE: ppb

MANUFACTURER/DEVELOPER: University of Washington

Dept. of Chemistry, BG-10

Seattle, WA 98195 USA

DETECTION METHOD: Renewable indicator reagent, absorbance

SUPPORT EQUIPMENT: Syringe pump, lamp, spectrometer, detector, fiber optics

CAPABILITIES: VAPOR: N LIQUID: $Y$ REVERSIBLE : $Y$

STATE OF DEVELOPMENT: Lab research

REFERENCES: Berman, R.J., and L.W. Burgess, 1989, Renewable Fiber optic Based Ammonia Sensor. SPIE Proceedings, Boston, MA, p. 206-212. 
NPPELDIX D

ph Sansor: 


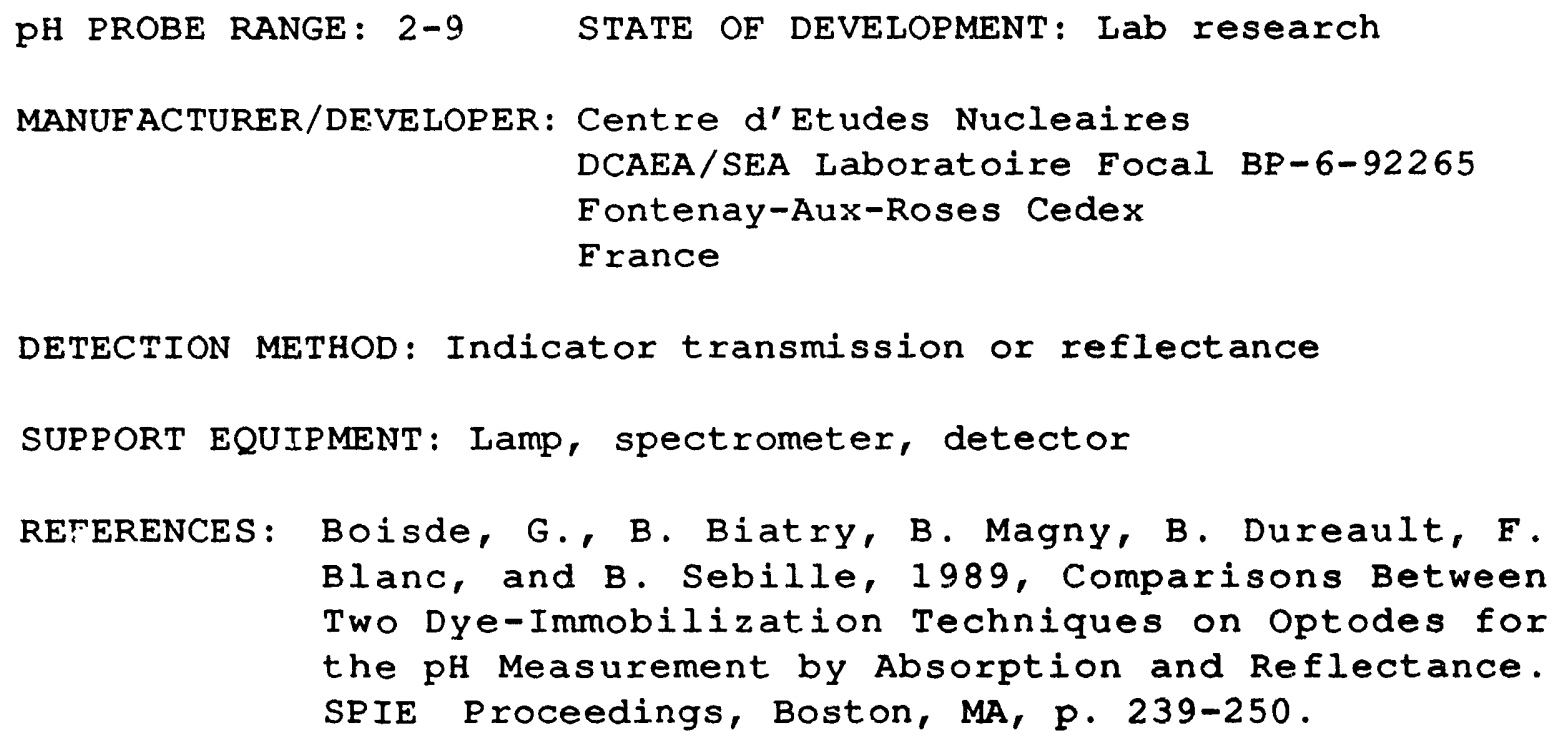

pH PROBE RANGE : 4-11 STATE OF DEVELOPMENT: Field tested

MANUFACTURER/DEVELOPER: University of Manchester

UMIST, P.O. Box 88

Manchester M60 1QD

Great Britain

DETECTION METHOD: Indicator on polymer, reflectance

SUPPORT EQUIPMENT: Lamp, spectrometer, detector

REFERENCES: Alabbas, S.H., D.C. Ashworth, and R. Narayanaswamy, 1989, Design and Characterization Parameters of an Optical Fibre pH Sensor. SPIE Proceedings, Boston, MA, p. 251-263.

Kirkbright, G.F., R. Narayanaswamy, and N.A. Welti, 1984, Fiber-Optic pH Probe Based on the Use of an Immobilised Colorimetric Indicator. Analyst, 109: 1025-1028. 
PH PROBE RANGE: 3-8 STATE OF DEVELORMENT: Lab research

MANUFACTURER/DEVELOPER: U.S. Army Chemical Research

Aberdeen Proving Ground

MD 21010-5423

USA

DETECTION METHOD: Chemical reaction with alizarin yellow, reflectance

SUPPORT EQUIPMENT: Lamp, spectrometer, detector, fiber optics

REFERENCES: Smardzewski, R.P., 1988, Multi-Element Optical Waveguide Sensor: General Concept and Design. Talanta, 35: 95-101.

pH PROBE RANGE: 3-9 STATE OF DEVELOPMENT: Lab research

MANUEACTURER/DEVELOPER: University of New Hampshire

Dept. of Chemistry

Durham, NH 03824

USA

DETECTION METHOD: Fluorescence, spectrophotometry, indicator

SUPPORT EQUIPMENT: Fiber-optic photometer, fluorometer

REFERENCES: Wangbai, M., Z. Zhujun, and W.R. Seitz, 1989, Poly (vinyl alcohol)-Based Indicators for Optical pH and $\mathrm{Mg}$ (II) Sensing. AC.S Symposium Series No. 403, Chemical Sensors and Microinstrumentation. 


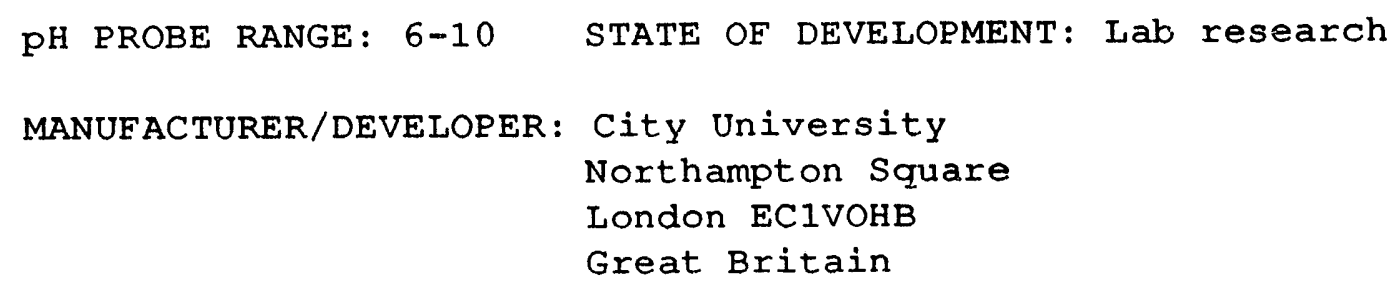

DETECTION METHOD: Chemical reaction, absorption spectroscopy

SUPPORT EQUIPMENT: Lamp, spectrometer, detector

REFERENCES: Grattan, K.T.V., Z. Mouaziz, and A.W. Palmer, 1987, Dual Wavelength optical Fiber sensor for pH Measurement. Biosensors, 3: 17-25.

Benaim, N., K.T.V. Grattan, and A.W. Palmer, 1986, Simple Fibre Optic pH Sensor for Use in Liquid Titrations. Analyst, 111: 1095-1097.

pH PROBE RANGE: 5-9 STATE OF DEVELOPMENT: Lab research

MANUFACTURER/DEVELOPER: Universidad Complutense

Departamento de Quimica Analitica

28040 Madrid

Spain

DETECTION METHOD: Chemical reaction with cresol red, reflectance measurement

SUPPORT EQUIPMENT: Lamp, spectrophotometer, photomultiplier

REFERENCES: Moreno, M.C., A. Martinez, P. Millan, and C. Camara, 1986, Study of a pH Sensitive Optical Fibre Sensor Based on the Use of Cresol Red. J. of Mol. Struc., 143: 553-556. 
PH PROBE RANGE: 6-9 STATE OF DEVELOPMENT: Lab research

MANUFACTURER/DF.VELOPER: University of New Hampshire

Dept. of Chemistry

Durham, NH 03824

USA

DETECTION MEIHOD: Chemical reaction with HOPSA, fluorescence

SUPPORT EQUIPMENT: Fluorometer

REFERENCES: Zhujun, $z$, and W.R. Seitz, 1984, A Fluorescence Sensor For Quantifying $\mathrm{pH}$ in the Range From 6.5 to 8.5. Anal. Chim. Acta, 160: 47-55.

pH PROBE RANGE: 0-14 STATE OF DEVELOPMENT: Field tested

MANUFACTURER/DEVELOPER: U.S. EPA

Environmental Monitoring and Support Lab

Res. Tri. Park, NC 27711

USA

DETECTION METHOD: Liquid sensor triggers covered sampler to open, rain is collected in sampling vials for analysis

SUPPORT EQUIPMENT: Liquid sensor, $\mathrm{pH}$ and conductivity probes

REFERENCES: Paur, R.J., 1987, Development and Evaluation of a Real-Time $\mathrm{pH}$ and Conductivity Rain Monitox. U.S. EPA Report 600/S4-87/010. 
PH PROBE RANGE: 6-9 STATE OF DEVELOFMENT: Lab research

MANUFACTURER/DEVELOPER: University of Pisa

Centro "E. Piaggio", Faculty of ingineering

Pisa, Italy

DETECTION METHOD: Absorbance of light by a pH-sensitive

indicator (phenol red)

SUPPORT EQJIPMENT: Lamp, spectrometer, detector

REFERENCES: Monici, M., R. Boniforti, G. Buzzigoli, D. De Rossi, and A. Nannini, 1987, Fibre-Optic pH Sensor for Seawater Monitoring. SPIE Proceedings, The Hague, The Netherlands, p. 294-300.

pH PROBE RANGE: 0-14 STATE OF DEVELOPMENT: Lab research

MANUFACTURER/DEVELORER: Centre d'Etudes Nucleaires

de Fontenay-aux-Roses.

92265 Fontenay-aux-Roses

Cedex, France

DETECTION METHOD: Absorption of light using colox indicator

SUPPORT EQUIPMENT: LED, Spectrometer, detector

REFERENCES: Boisde, G., and J.J. Perez, 1987, Miniature Chemical Optical Fiber Sensors for $\mathrm{pH}$ Measurements. SPIE Proceedings, The Hague, The Netherlands, $p$. 238-245. 
pH PROBE RANGE: 5-8 STATE OF DEVELOPMENT: Lab research

MANUFACTURER/DEVELOPER: Catholic University of America

Vitreous State Laboratory

Washington, DC 20064

USA

DETECTION METHOD: Reflectance of indicator in gold-coated porous fiber optic probe

SUPPORT EQUIPMENT: Lamp, filter or monochromator, detector

REFERENCES: Finger, S.M., P.B. Macedo, A. Barkatt, H. Hojaji, N. Laberge, R. Mohr, and M. Penafiel, 1989, Porous Glass Fiber Optic Sensors for Field Screening of Hazardous Waste Sites. First Annual Field Screening Methods for Hazardous Waste Site Investigations Proceedings, Las Vegas, NV, EPA/600/D-89/189.

PH PROBE RANGE: 4-9 STATE OF DEVELOPMENT: Lab research

MANUFA:TURER/DEVELOPER: Rutgers University

Fiber Optic Materials Research Program

Piscataway, NJ 08903

USA

DETECTION METHOD: Evanescent absorption of light by indicator in porous glass fiber probe

SUPPORT EQUIPMENT: Lamp, filter or monochromator, detector, fiber optics

REFERENCES: Shahriari, M.R., Q. Zhou, G.H. Sigel Jr., and G. Stokes, 1989, Porous Fiber Optics for Chemical Sensing. First Annual Field Screening Methods for Hazardous Waste Site Investigations Proceedings, Las Vegas, NV, EPA/600/D-89/189. 
PH PROBE RANGE: 4-8 STATE OF DEVELOPMENT: Lab research

MANUFACTURER/DEVELOPER: Tufts University

Max Tishler Lab. for Organic Chemistry

Medford, MA 02155

USA

DETECTION METHOD: Laser-induced fluorescence of indicator

on polymer

SUPPORT EQUIPMENT: Laser, monochromator, PMT

REFERENCES: Munkholm, C., D.R. Walt, F.P. Milanovich, and S.M. Klainer, 1986, Polymer Modification of Fiber Optic Sensors as a Method of Enhancing Fluorescence Signal for $\mathrm{pH}$ Measurement. Anal. Chem., 58: 14271430 .

PH PROBE RANGE: ? STATE OF DEVELOPMENT: Lab research

MANUFACTURER/DEVELOPER: LOS Alamos National Laboratory

Los Alamos, NM 87545

USA

DETECTION METHOD: Conductive polymer

REFERENCES: Carey, P., V. Hamilton, P. Mendoza, L. Wangen, W. Smith, B. Jorgensen, G. Jarvinen, and P. Smith, 1989, Chemical Sensors. LA-11715-MS UC-701. 


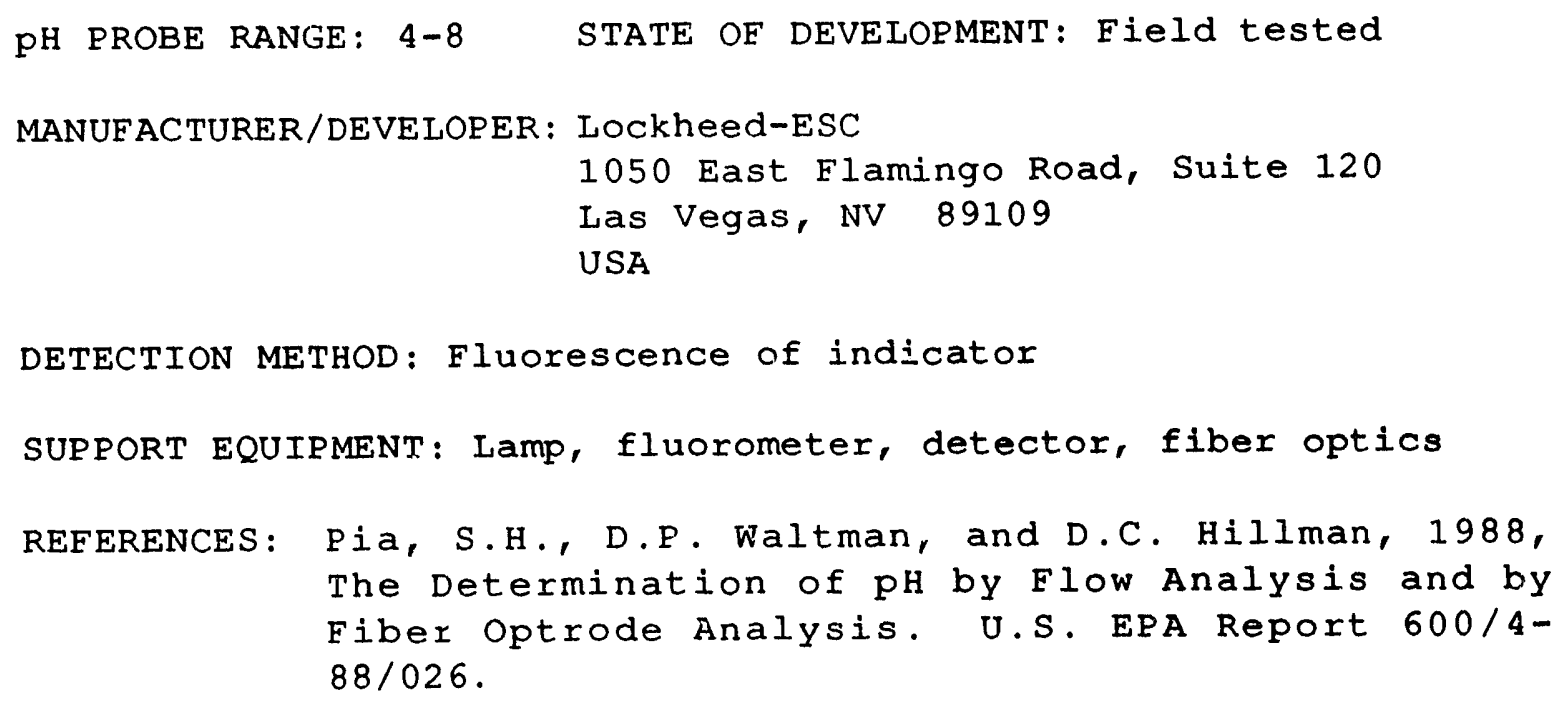

PH PROBE RANGE: 5-8 STATE OF DEVELOPMENT: Lab research

MANUFACTURER/DEVELOPER: Tufts University

Dept. of Civil Engineering

Medford, MA 02155

USA

DETECTION METHOD: Fluorescence of controlled-release dyes

SUPPORT EQUIPMENT: Lamp, fluorometer, detector, fiber optics

REFERENCES: Luo. S., and D.R. Walt, 1989, Fiber-Optic Sensors Based on Reagent Delivery with Controlled-Release Polymers. Anal. Chem., 61: 174-177. 
PH PROBE RANGE: ?

STATE OF DEVELOPMENT: Commercial

MANUFACTURER/DEVELOPER: HYdrolab

P.O. Box 50116

Austin, TX 78763

USA

DETECTION METHOD: Glass electrode with specal low ionic strength reference electrode

SUPPORT EQUIPMENT: Multiparameter logging system

REFERENCES: Hydrolab Manufacturers, 1991, The Hydrolab Surveyer III, Manufacturer's Literature.

pH PROBE RANGE: ? STATE OF DEVELOPMENT: Lab research

MANUFACTURER/DEVELOPER: University of New Hampshire

Dept. of Chemistry

Durham, NH 03824

USA

DETECTION METHOD: Fluorescence of bound indicator

SUPPORT EQUIPMENT: Lamp, fluorometer, detector, fiber optics

REFERENCES: Saari, L.A., and W.R. Seitz, 1982, pH Sensor Based on Immobilized Fluoresceinamine. Anal. Chem., 54: $821-823$. 
APPENDIX E

Miscellaneous seneore 
COMPOUND CLASS DETECTED: Gaseous inorganic

ANALYTES: Ammonia

DETECTION LIMIT RANGE: ppm

MANUFACTURER/DEVELOPER: U.S. Naval Research Laboratory Washington, DC 20375 USA

DETECTION METHOD: Transmission of light through a capillary tube coated with a dye

SUPPORT FQUIPMENT: Optical waveguide device, light source, spectometer, detector

CAPABILITIES: $\quad$ VAPOR: $Y$ LIQUID: $N$ REVERSIBLE: $Y$

STATE OF DEVELOPMENT: Lab research

REFERENCES: Giuliani, J.F., H. Wohltjen, and N.L. Jarvis, 1983, Reversible Optical Waveguide Sensor for Ammonia Vapors. Optics Letters, 8(1): 54-56. 
COMPOUND CLASS DETECTED: Gaseous inorganic

ANALYTES: Ammonia

DETECTION LIMIT RANGE: pPm

MANUFACTURER/DEVELOPER: Rutgers University

Fiber Optic Materials Research Program

Piscataway, NJ 08903 USA

DETECTION METHOD: Evanescent absorption of light by

indicator in a porous glass fiber probe

SUPPORT EQUIPMENT: Lamp, filter or monochromator, detector, fiber optics

CAPABILITIES :

VAPOR: $Y$

IIQUID : $\mathrm{N}$

REVERSIBLE : Y

STATE OF DEVELOPMENT: Lab research

REFERENCES: Shahriari, M.R., Q. Zhou, G.H. Sigel Jr., and G. Stokes, 1989, Porous Fiber Optics for Chemical Sensing. First Annual Field Screening Methods for Hazardous Waste Site Investigations Proceedings, Las Vegas, NV, EPA/600/D-89/189. 
COMPOUND CLASS DETECTED: Peroxide

ANALYTES: Hydrogen peroxide

DETECTION LIMIT RANGE: ppm

MANUFACTURER/DEVELOPER: University of New Hampshire

Dept. of Chemistry

Durham, NH 03824 USA

DETECTION METHOD: Chemical reaction with luminol, chemiluminescence

SUPPORT EQUIPMENT: Magnetic stirrer, light shield, fiber optics, photomultiplier, recorder

CAPABILITIES:

VAPOR: $N$

LIQUID : Y

REVERSIBLE : $Y$

STATE OF DEVELOPMENT: Lab research

REFERENCES: Fre eman, T.M., and W.R. Seitz, 1978 , Chemiluminescence Fiber Optic Probe for Hydrogen Peroxide Based on the Luminol Reaction. Anal. Chem., 50: 1242-1246. 
COMPOUND CLASS DETECTED: Phyloplankton

ANALYTES: Phyloplankton

MANUFACTURER/DEVELOPER: Emory University

1515 Pierce Drive

Atlanta, GA 30322 USA

DETECTION METHOD: Multidimensional fluorescence

SUPPORT EQUIPMENT: Lamp, monochromator, intensified

diode array

CAPABILITIES: $\quad$ VAPOR: $N$ LIQUID: $Y$ REVERSIBLE : $Y$

STATE OF DEVELOPMENT: Lab research

REFERENCES: Zung, J.B., R.L. Woodlee, M-R.S. Fuh, and I.M. Warner, 1988, Fiber Optic Based Multidimensional Fluorometer for Studies of Marine Pollutants. SPIE Proceedings, Boston, MA, p. 49-54. 
COMPOUND CLASS DETECTED: Phytoplankton

ANALYTES: Phytoplankton

DETECTION LIMIT RANGE: ppm

MANUFACTURER/DEVELOPER: Royal Norwegian Council for Scientific

and Industrial Environmental Surveillance

Technology Programme

Norway

DETECTION METHOD: Fluorescence

SUPPORT EQUIPMENT: Lamp, fluorometer, fiber optics

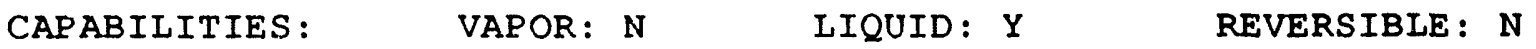

STATE OF DEVELOPMENT: Field tested

REFERENCES: Lund, Terje, 1983, A Fiber Optics Fluorimeter for Algae Detection and Mapping. International Conference on Optical Fibre Sensors, p. 190-194. 
COMPOUND CLASS DETECTED: Various

ANALYTES: TOXic gases

MANUFACTURER/DEVELOPER: CEA Instruments, InC.

16 Chestnut Street

Emerson, NJ 07630 USA

DETECTION METHOD: Membrane galvanic cell (electrochemical)

SUPPORT EQUIPMENT: Ancillary electronics

CAPABILITIES: VAPOR: $Y$ LIQUID : $N$ REVERSIBLE: $Y$

STATE OF DEVELOPMENT: Commercial

REFERENCES: CEA Instruments, Inc. Portable and Fixed Systems for Toxic Gas Detection. Manufacturer Product Guide. 
COMPOUND CLF.SS DETECTED: Various

ANALYTES: Custom applications

MANUFACTURER/DEVELOPER: Guided Wave/Perstorp

5190 Golden Foothill Parkway

El Dorado Hills, CA 95630 USA

DETECTION METHOD: UV-VIS-NIR analysis

SUPPORT EQUIPMENT: Scanning spectrophotometer, optical

multiplexers, computer, fiber optic probe

CAPABILITIES: VAPOR: N IIQUID: $Y$ REVERSIBLE: $Y$

STATE OF DEVELOPMENT: Commercial

REFERENCES: Guided Wave, 1990, In Situ UV-VIS-NIR Analysis Without Being There. Information Circular No. 83, El Dorado Hills, CA. 
COMPOUND CLASS DETECTED: Various

ANALYTES: Custom Applications

MANUFACTURER/DEVELOPER: ST\&E, InC.

1214 Concannon Boulevard

Livermore, CA 94550 USA

DETECTION METHOD: Optical spectroscopy

SUPPORT EQUIPMENT: Iamp, spectrometer, detector, fiber optics

CAPABILITIES: $\quad$ VAPOR: $Y$ LIQUID: $Y$ REVERSIBLE : $Y$

STATE OF DEVELOPMENT: Lab research

REFERENCES: Klainer, S.M., J.M. Harris, and K. Goswani, 1989, Modular Fiber Optic Chemical sensor. U.S. Pat. $4,824,206$. 
COMPOUND CLASS DETECTED: Various

ANALYTES: Custom Applications

DETECTION IIMIT RANGE: varies

MANUFACTURER/DEVELOPER: VOlPi Manufacturing USA

26 Aurelius Avenue

Auburn, NY 13021 USA

DETECTION METHOD: Optical spectroscopy

SUPPORT EQUIPMENT: Light source, detector, fiber optics

CAPABILITIES: VAPOR: $N$ LIQUID: $Y$ REVERSIBLE : $Y$

STATE OF DEVELOPMENT: Commercial

REFERENCES: Volpi Manufacturing Literature, 1991. 
COMPOUND CLASS DETECTED: Various

ANALYTES: Custom Applications

MANUFACTURER/DEVELOPER: NIRS SYstems, InC.

2441 Linden Lane

Silver Spring, MD 20910 USA

DETECTION METHOD: Near infrared spectroscopy (NIRS)

SUPPORT EQUIPMENT: Infrared source, spectrometer, detector, fiber optics

CAPABILITIES:

VAPOR: $\mathrm{N}$

LIQUID : Y

REVERSIBLE : Y

STATE OF DEVELOPMENT: Commercial

REFERENCES: Bickel, A., 1990, NIR Systems Product Literature, p. 94-96. 
COMPOUND CLASS DETECTED: Various

ANALYTES: Custom Applications

MANUFACTURER/DEVELOPER: Guided Wave/Perstorp 5190 Golden Foothill Parkway

El Dorado Hills, CA 95630 USA

$\begin{aligned} \text { DETECTION METHOD: } & \text { Optical spectroscopy with multivariate } \\ & \text { analysis for the analysis of mixtures }\end{aligned}$

SUPPORT EQUIPMENT: Lamp, spectrometer, detector, computer, multivariate analysis software, fiber optics

CAPABILITIES: $\quad$ VAPOR: N LIQUID: $Y$ REVERSIBLE: $Y$

STATE OF DEVELOPMENT: Commercial

REFERENCES: Foulk, S., and G. Gargus, 1987, Fiber-optic Spectroscopy and Multivariate Analysis for In Situ Chemical Monitoring. American Laboratory, Dec, p. $52-53$. 
COMPOUND CLASS DETECTED: Various

ANALYTES: Custom Appplications

MANUFACTURER/DEVELOPER: Cordis Corporation

Miami, FI USA

DETECTION METHOD: Optical spectroscopy of indicator on photocrosslinked polymeric gel

SUPPORT EQUIPMENT: Lamp, spectrometer, detector,
fiber optics

CAPABILITIES: VAPOR: N LIQUID: $Y$ REVERSIBLE: $Y$

STATE OF DEVELOPMENT: Lab research

REFERENCES: Blaylock, M.E., 1989, Method of Producing Fipe: Optic chemical sensors Incorporatijg Photocrosslinked Polymer Gels. U.S. Paf. $4,842,783$. 

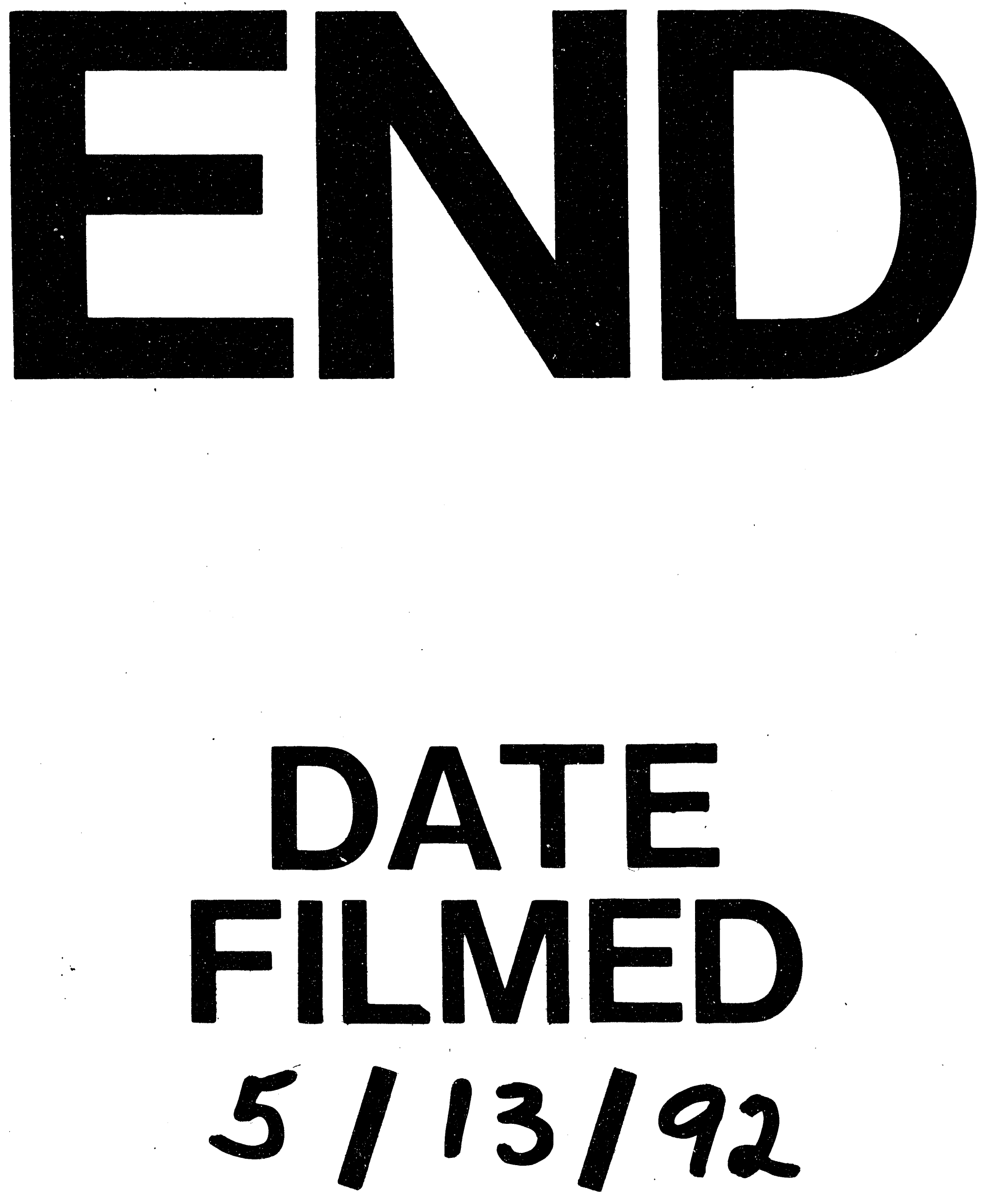

I 
